\title{
Purificação da experiência e conhecimento absoluto do real: a metafísica como intuição da duração
}

\author{
Débora Cristina Morato Pinto
}

Professora da Universidade Federal de São Carlos (UFSCar) 


\section{Purificação da experiência e conhecimento absoluto do real: a metafísica como intuição da duração}

Pretendemos aqui mostrar que o vínculo indissociável entre crítica da inteligência e intuição da duração acarreta a nova definição da metafísica: "experiência integral", segundo Bergson. A relação entre o trabalho de desqualificação de ilusões racionais e a redescoberta do ser como duração expõe, desse modo, como a consciência pode voltar a seus próprios dados e neles encontrar uma experiência real e inegável, a da presença do ser e de nosso pertencimento ao ser. A filosofia bergsoniana procura, nesse âmbito, conjugar reflexibilidade e sensibilidade. Em suas duas primeiras obras, pelo estudo profundo e detalhado dos processos psicológicos, Bergson defende que a consciência à qual a duração apareceria é a mesma que se toma como objeto, "espectadora e atriz". A consciência age e vê, é o ver do fazer - ou, antes, do fazer-se. A duração que apareceria à consciência é a própria consciência: a consciência da duração e a duração da consciência estariam identificadas nessa visão.

Palavras-chave: consciência, percepção, visão, totalidade, ser, duração

\section{Experience purification and absolute knowledge of the real: metaphysics as lasting intuition}

We intend to show that the steadfast link between criticism of intelligence and intuition of duration leads to the new definition of metaphysics - 'full experience', as Bergson puts it. The relationship between the task of disqualifying rational illusions, and the rediscovery of being as duration thus shows how consciousness can fall back on its own data and there discover a real and undeniable experience - that of the presence of being and of our belonging to being. In this context, Bergson's philosophy seeks to combine reflexivity and sensitivity. Having studied psychological processes in depth and detail, Bergson argues, in his first two works, that the consciousness to which duration appears is that which is taken to be the object - at once "the spectator and the actress". The duration that appears to consciousness is consciousness itself: according to this view, consciousness of duration and duration of consciousness are one and the same.

Key words: conscience, perception, vision, totality, being, duration 
Mais si la métaphysique doit procéder par intuition, si l'intuition a pour objet la mobilité de la durée, et si la durée est d'essence psychologique, n'allons-nous pas enfermer le philosophe dans la contemplation exclusive de lui-même? La philosophie ne vat-elle pas consister à se regarder simplement vivre, comme un pâtre assoupi regarde l'eau couler?

Bergson $^{1}$

\section{Crítica da razão e retorno aos dados imediatos: ilusão e verdade}

Bergson define com frequência seu esforço filosófico como a busca por uma apreensão da realidade em sua essência, a visão da duração revelada "tal como é, criação contínua" (Bergson 3, p.1259) é Bergson quem insere seu pensamento no âmbito de uma investigação metafísica. Entretanto, desde o início das tentativas de obtêla essa visão está comprometida por um funcionamento natural de nossas capacidades cognitivas, os sentidos e a inteligência, que produzem da realidade uma representação infiel, porque direcionada pelas carências e intenções vitais: em suma, pelas necessidades da ação. O problema a ser enfrentado na reconstrução da metafísica é o velho dilema da articulação entre prática (ou mesmo técnica) e teoria. Se os instrumentos disponíveis ao conhecimento são intrínsecos à nossa condição humana, desenvolvidos no âmbito da vida, é

1 Introduction à la métaphysique. Bergson 3, p. 1416. 
pela atitude de libertação de tal condição, libertação sempre parcial e ambígua, que são superados certos limites e obtém-se o encontro entre o conhecimento e o ser. Sabemos que, na filosofia de Bergson, isso significa recuperar a temporalidade do real que se oculta sob os véus $^{2}$ da espacialidade necessária ao agir - a forma de representação indispensável à manutenção da vida. A forma espacial desenvolve-se e aperfeiçoa-se por meio de nossos hábitos mentais e é a principal responsável pela objetivação da realidade, pela constituição de uma objetividade que sempre apresenta algo de artificial e imaginária.

A aventura humana tomada em seu fluxo natural e social, já que "a natureza predestinou o homem à vida social" (Bergson 3, p. 1310), está fundada em processos cujo funcionamento deriva necessariamente da construção de recortes estáveis, corpos tendendo à invariabilidade, fixação de pontos e paradas indicados pelas finalidades ou desígnios da ação. A inteligência e a linguagem nada mais fazem do que seguir e tornar mais sofisticados esses processos e seus produtos, sempre instituídos por um desvio de tudo que, na experiência, é ato, progresso, transformação ou movimento. Consequentemente, a linguagem como ferramenta das ferramentas para a atividade intelectual responde por boa parte da tendência de nosso conhecimento a "ver na mudança e no movimento acidentes, a erigir a imutabilidade e a imobilidade em essências e substâncias, em suportes" (Idem, ibidem, p. 1311), visão e construção a que então estamos predestinados por nossa humanidade. Tal é o sentido da famosa afirmação bergsoniana: a metafísica do Ser idêntico e imutável (que é lógico e eterno) não fez nada além de "conformar-se aos hábitos da linguagem" (Idem, ibidem, p. 1256). A representação fiel da realidade (acesso à intuição imediata que supera, de algum modo, o próprio "cons-

2 A metáfora usada em algumas passagens reveladoras de sua obra é a de um véu que se interpõe entre nós e o real que procuramos conhecer. Quando se trata de acessar o espírito em seu fazer-se, trata-se do véu existente entre "nossa consciência e nós mesmos" (Bergson 3, p. 644), um véu que deforma o conteúdo da experiência. 
truto representacional") será, portanto, aquela capaz de ampliar os horizontes do pensamento discursivo.

A intenção maior de Bergson consiste em fundar outra metafísica, um "verdadeiro evolucionismo" que possa tomar o movimento e a mudança como reais, concentrando-se na apreensão direta do que se faz. Tal apreensão necessita partir do contato com o progresso dinâmico ou com o ato de ligação que define a duração real; a metafísica assim delineada identifica-se "à própria experiência" (Idem, ibidem, p. 1259). Para tanto, o desenvolvimento da filosofia consistirá em explorar os mais diversos campos de fenômenos pela incorporação da ligação, passagem ou progressão cuja realidade esse contato permite conferir. Mais que isso, os dois aspectos da duração que escapam aos hábitos mentais são aqueles cuja recuperação possibilitará superar a maior parte das dificuldades filosóficas, porque sua origem comum é a posição de questões à luz da estabilização do movente: Bergson considera que a má posição dos problemas filosóficos, equacionados a priori como insolúveis, remete à espacialização imanente à vida. À filosofia que pretende escapar dessa armadilha cabe, então, fazer um recuo e reiniciar o seu caminho por uma espécie de "desnaturalização" do conhecimento.

Com efeito, a questão enfrentada por Bergson ao tomar consciência do equívoco do senso comum e da tradição filosófica foi saber como desviar do caminho natural à inteligência, isto é, "desenraizar uma inclinação tão profunda, conduzir o espírito a inverter o sentido de sua operação habitual" (Idem, ibidem, p. 1311). E a chave da resposta encontrava-se justamente no cuidado em não abandonar o solo dessa mesma práxis, em recuperar na experiência sua origem, sua fonte, seu estado nascente. Tudo se joga no fato de que há uma dualidade essencial na existência humana: por um lado, sua inscrição no real pela ação deriva da negação de aspectos intrínsecos ao solo mesmo dessa inscrição (aspectos que depois se trata de reencontrar). Tal negação se efetiva pela ruptura do con- 
tínuo e pela fixação do movente, recorte e estabilização instituídos na experiência concreta. Por outro lado, a dimensão originária da experiência é o contato com a continuidade movente subjacente à ação, contato cujo verdadeiro significado reaparece à consciência por uma nova inserção no real, agora teórica, uma experiência propriamente metafísica ${ }^{3}$ que retoma a mutabilidade e a continuidade, e compreende então a realidade como durée. Uma dualidade inscrita na vida humana que se explicita, como defende Worms, na distinção conceitual central ao pensamento de Bergson, cujo sentido se espalha por todas as obras: a diferença entre espaço e duração. Transformar a duração em espaço ou determinar a sucessão como justaposição no tempo homogêneo, ato que institui nossa representação "natural" das coisas, é uma confusão teórica inevitável à nossa vida que, por isso mesmo, essa confusão deixa escapar a própria vida no que ela tem de essencial: "a confusão do espaço com o tempo nos oculta a realidade de nossa vida interior em nome das necessidades práticas" (Worms 18, p. 10). A vida se exerce pela espacialização, mas seu solo não é eminentemente espacial, ou antes, a espacialização é uma modulação rítmica do tempo, que, entretanto, vai no sentido oposto ao do mesmo - compreender o "caráter último dessa dualidade" (Idem, ibidem, p. 11). Assim, retomar a unidade possível de um dualismo aparentemente essencial significa atingir a profundidade do pensamento bergsoniano. ${ }^{4}$

3 O que enfatizamos aqui é a ligação inseparável e essencial entre experiência e metafísica, reafirmada por Bergson em contextos de definição e exposição geral de sua doutrina. Assim, na introdução a La pensée et le mouvant, ao descrever seu esforço crítico como trabalho de remoção da casca conceitual que "liberta a crisálida", ele aponta como as grandes dificuldades da filosofia desapareceriam ou restariam sobre a película superficial, e isso significaria transformar a metafísica na "própria experiência"(Bergson 3, p. 1259). A relação entre esse vínculo e a intuição é o que lança luz à inversão proposta por Bergson, já que o movimento da intuição entre dois limites da duração é também dito "a própria metafísica" (Idem, ibidem, p. 1419).

4 Essa é a proposta do vigoroso trabalho de Worms em Bergson ou les deux sens de la vie. Trata-se de um estudo detalhado das principais obras bergsonianas à luz dessa hipótese central, a de que a distinção entre durée e espaço abre um "acesso metafísico aos dois 
A ação natural e mesmo social nega e oculta a temporalidade; a experiência integral pela qual Bergson define a metafísica ${ }^{5}$ trata de recuperar aquilo que ficou sedimentado pelos expedientes da ação - a relação entre teoria e prática assim configurada é de oposição, inversão e interrupção. Daí a necessidade incontornável de um longo trabalho crítico para superar o ponto de vista da práxis e redescobrir o tempo na efetivação de um conhecimento absoluto - sem crítica como desvendamento da origem de conceitos e ilusões da velha teoria, nada de intuição da duração. Mas a originalidade do modo como pela qual Bergson enfrenta a oposição entre teoria e prática, conhecimento e ação, só pode ser compreendida ao se considerar em detalhe sua redescrição da experiência consciente, em especial a inserção no mundo pelo processo originário da percepção,e que articula temporalidade e espacialidade numa mistura cujo sentido último responde pela unidade especial da duração. Mais que isso, o exame das relações entre o sujeito e o mundo identifica-se à compreensão da psicologia como ontologia, ou a passagem de uma psicologia da consciência a uma metafísica como intuição da durée. A metafísica como expressão pura da teoria não pode deixar de colocar questões à psicologia, precisamente a ciência que estuda "o espírito humano funcionando utilmente para a prática” (Bergson 3, p. 167); e vice-versa, pois os mais relevantes temas do campo psicológico recebem também problemas e indicações de soluções provenientes da metafísica. Toda a filosofia de Bergson gira em torno dessa relação,

sentidos 'da' vida ou de nossa vida” (Worms 18, p. 29), o que significa tomar a sério o fato de que ela é teórica e prática e, assim, intervém na nossa vida.

5 Trata-se da expressão final de Introduction à la Métaphysique. Ao apresentar pela primeira vez uma exposição de um programa para a metafísica, Bergson enfrenta a complexa relação entre metafísica e ciência, indicando os limites da reflexão moderna e os meios de superá-la. Insiste, no seu momento final, na diferença entre o que está propondo e a identificação da metafísica a uma síntese ou generalização dos conhecimentos "materiais" obtidos no campo da ciência: "Nesse sentido, a metafísica não tem nada em comum com uma generalização da experiência e, entretanto, poderia se definir como a experiência integral" (Bergson 3, p. 1432). 
pois num certo sentido o "ser psicológico" é o próprio ser temporal. Assim, outro modo de compreender a definição de metafísica como "a própria experiência" é considerar a frase que encontramos nesse mesmo trecho de Matéria e memória, livro cujo percurso expõe de modo exemplar o vínculo entre teoria e prática aqui delineado: a metafísica consiste nesse "mesmo espírito humano esforçando-se para desembaraçar-se das condições da ação útil e para assumir-se como pura energia criadora" (Idem, ibidem, p. 167).

Alcançar os objetivos últimos da metafísica como conhecimento absoluto encaminha Bergson à tentativa de explorar todas as dimensões da experiência, a fazer girar suas análises em torno da consciência interna e externa. Compreender tal exploração significa, numa certa perspectiva, recuperar o sentido da noção de intuição como visão, mas agora como conjunção entre visão e ação conjunção que é permeada pela reflexão. Isso implica posicionar-se com ressalvas diante das leituras que recolheram a intuição à vida interior, ao exercício espiritual que recusa a práxis (ou a ela apenas impõem o papel de obstáculo à verdadeira filosofia). Em outros termos, não basta definir a filosofia bergsoniana pelo "primado da vida interior" e reconhecer seu itinerário como busca incessante de uma "experiência metafísica como conversão à interioridade" (Vieillard-Baron 15, p. 54); ${ }^{6}$ é indispensável resolver o enigma da passagem da duração do eu à duração das coisas, fundada justamente numa conversão da percepção. O operador da conversão é a crítica do conhecimento usual, mas, não custa repetir, trata-se de

6 A insistência enfática na vida interior conduz o autor a discordar veementemente das leituras de Bergson que tomam Matéria e memória como foco central, ou seja, aquelas que procuram ressaltar a ligação intrínseca entre a interioridade própria à duração e sua potência de manifestação - como ser e aparecer são indissociáveis na filosofia da duração - , em suma, a leitura bergoniana como ontologia da Presença, desenvolvida por Bento Prado Jr. e retomada por autores ligados à fenomenologia, como Renaud Barbaras. Ao analisar tais autores mediante o fio condutor da experiência da duração na vida interior, Vieillard-Baron negligencia aspectos da duração essenciais à passagem da duração interna à duração em geral de $A$ evolução criadora. 
realizar uma crítica reflexiva no próprio campo da experiência, o que se explicita pela descrição da intuição como consciência ampliada e "visão direta do espírito pelo espírito" (Bergson 3, p. 1273).

A origem prática do conhecer implicou, desde sempre, negar aspectos da realidade, precisamente aqueles que escapam à determinação conceitual, negação que está no núcleo da história da filosofia. No mínimo, deveria haver um questionamento sobre a diferença entre finalidade prática e intenção teórica por parte dos filósofos, e isso foi justamente o que não fizeram. Eles não puseram em questão os princípios que seguiam ao formular interrogações radicais; seguiram, assim, impulsionados por um "motor invisível" (Idem, ibidem, p. 728) do pensamento. ${ }^{7}$ A filosofia desenvolve-se, nesse contexto, mergulhada em ilusões naturais ao entendimento que se originam no campo prático, ascendem a um terreno abstrato e retroagem sobre o conhecimento de um modo geral. Torna-se indispensável, então, um esforço de desconstrução das ilusões para impedir que concepções já sedimentadas operem silenciosamente na descrição do real: “é preciso desfazer as ilusões que servem de horizonte à práxis humana e lhe emprestam vigor" (Prado Jr. 12, p. 89); esse movimento de inversão da tendência intelectual é também "interrupção da prática" (Idem, ibidem, p. 89). Ora, interrupção e inversão não significam negação, nem ocultamento, nem esquecimento - quem assim procede é o

7 Trata-se de expressão encontrada no inventário das ilusões no último capítulo de L'Évolution Créatrice. Esse motor estaria operando desde o equacionamento das questões metafísicas no âmbito do pensamento pré-socrático, que lança as direções a partir das quais a filosofia clássica se desenvolverá. Esse quadro inicial que marca a origem do pensamento grego exige da verdadeira filosofia o imenso trabalho crítico que a obra de Bergson nos apresenta - de onde as referências constantes a Zenão de Eleia como pai da metafísica. Na conferência La perception du changement, de 1911, o problema do movimento é retomado como capital: "se estivéssemos convencidos da realidade do movimento e se fizéssemos esforço para reapreendê-lo, tudo se simplificaria”. Bergson não se cansa de explicitar a relação entre a escola de Eleia e o caminho trilhado pela filosofia grega imediatamente posterior. Sobre isso ver da autora "Crítica da tradição, refundação da metafísica e descrição da experiência - Bergson e Merleau-Ponty” (Morato Pinto 10, p. 25-40). 
conhecimento obcecado pela estabilidade das coisas. A experiência concreta sofrerá, então, um exame crítico e nos fornecerá de si mesma os índices de sua própria verdade.

Em outros termos, o trabalho de denunciar e desfazer as ilusões, modulando a obra da inteligência (isto é, a mediação do espaço e dos conceitos), recupera a verdade do contato originário entre o sujeito da experiência e o conteúdo, um entorno que se trata de acompanhar. Esse contato é, a um só tempo, origem e objeto de negação para a ação vital e para o conhecimento por ela secretado: é ele que deve ser recuperado para a transformação do conhecimento em metafísica. A teoria pautada pela verdade retorna à prática e a compreende, encontrando no seu campo o próprio ser. A filosofia necessita então da remodelação da relação entre teoria e prática. Essa ruptura diz respeito aos processos de conhecimento e ao modo pelo qual o sujeito vê sua inserção no mundo, continuidade entre as dimensões do campo ao qual o conhecimento se aplica - a experiência consciente interna e externa, os "dois centros de observação" que se trata de compreender em sua implicação mútua. $\mathrm{Na}$ verdade, a relação entre interioridade e exterioridade é postulada por Bergson como único caminho verdadeiro para a filosofia, que deve "proporcionar uma experiência integral da realidade, equilíbrio entre dois centros de observação" (Silva 13, p. 44), centros estes que se definem como a experiência interna e a observação externa. ${ }^{8}$

O conhecimento teórico que apenas prolongar os expedientes da prática dará continuidade ao que podemos chamar, tomando de empréstimo a Merleau-Ponty, atitude natural, definida pelos processos pelos quais a vida se exerce: a ruptura e a fixação. Ambos são condicionados pela constituição de um meio vazio e homogêneo, a forma espacial que é condição a priori da objetividade. Esse conhecimento concretizou-se na história da ciência e da metafísica, fundadas na es-

8 Isso inclui também o terreno da ciência: "o filósofo deveria incorporar a experiência científica e cotejá-la com a experiência interna metodicamente desenvolvida, foco de luz que o conduziria na interpretação dos fatos" (Silva 13, p. 44). 
pacialização do real que se exerce em diversos níveis de intensidade. Mais explicitamente, seja a dimensão material da realidade, seja o espírito manifestando-se no pensamento, é da índole da nossa apreensão natural dos objetos representá-los como “já feitos", impondo à sua manifestação uma forma de aparecer que se opõe ao seu caráter dinâmico, à sua transformação incessante, ao seu fazer-se que é seu próprio ser, seu "perpétuo devir". A transformação e a mobilidade desaparecem, portanto, aos olhos da consciência comum e científica, e a representação intelectual da realidade impede que a filosofia veja "na duração o próprio tecido de que a realidade é feita" (Bergson 3, p. 744). Desse modo, o conhecimento especulativo da tradição que não fez a crítica de seus fundamentos apenas ampliou e aplicou potências desenvolvidas no âmbito da práxis. E, se a proposta de um conhecimento absoluto dessa realidade encontra obstáculos intrínsecos ao seu próprio começo, isso se dá apenas na medida em que o espírito confia inteiramente nos instrumentos já à sua disposição, talhados na medida exata da luta pela vida, do enfrentamento das dificuldades impostas pela matéria, da organização do trabalho coletivo e das relações sociais por ele estabelecidas. ${ }^{9}$ Esses instrumentos, que têm na linguagem o seu mais alto grau de desenvolvimento, culminam inevitavelmente na representação do real instituída pela negação do movimento e, sobretudo, do tempo, a representação de

9 O conhecimento produzido por esses instrumentos, seguindo a trilha da percepção e de seu desenvolvimento em linguagem e inteligência, acaba por enquadrar o real em categorias, conceitos ou ideias gerais. Trata-se do modo de pensamento que derivou diretamente da linguagem da práxis e se constitui modelado pelo funcionamento que lhe é inerente: a lógica da predicação, que atribui o estável ao estável, é própria da linguagem enquanto instrumento de socialização, do trabalho em comum, e engendra a representação da mudança como justaposição de estados ou sucessão de qualidades estáveis, formulada magistralmente pelo pensamento grego. Além disso, a consideração da mudança como acidente e da imobilidade como essência é também fruto da nossa percepção: esta recorta, na continuidade da extensão, corpos escolhidos precisamente de modo a poderem ser tratados como invariáveis durante o tempo em que os consideramos; em suma, "a percepção, o pensamento, a linguagem, todas as atividades individuais e sociais do espírito contribuem para nos pôr em presença de objetos que podemos tomar como invariáveis e imóveis durante o tempo em que os considerarmos" (Bergson 3, p. 1310). 
uma eternidade imóvel e idêntica do Ser — eternidade que é, como dissemos, natural e ilusória. À filosofia cabe, assim, retomar o solo sobre o qual essa representação se construiu para atingir sua origem e denunciar sua inadequação, ou seja, efetivar a inversão acima citada: "Filosofar consiste em inverter a direção habitual do trabalho do pensamento" (Idem, ibidem, p. 1422).

A atitude natural e o conhecimento que a prolonga não veem o estofo da realidade. Essa cegueira prolongada produz as duas ilusões que são a espinha dorsal do entendimento, a da Estabilidade (substituição do devir por uma forma estável) e a do Nada (pensamento do ser à luz da precedência do vazio, da ausência). Em outros termos, a incapacidade intelectual para dar conta da realidade induz a um certo tipo de metafísica construída em torno das ilusões da razão. A ideia do $\mathrm{Nada}^{10}$, segunda ilusão capital da razão apresentada no inventário que fecha A evolução criadora, é a que transforma o pleno em vazio, a presença em ausência, precisamente porque responde a uma função da ação vital, satisfação de carências, preenchimento de necessidades ou dos buracos no ser humano em luta com a realidade. Ele é "parente" da ilusão da estabilidade porque tem a mesma origem: aplicação de procedimentos da práxis à teoria. Mas o aspecto da ação que predomina na produção da ideia do nada é o fato de que seu fim ou objetivo sempre se constitui à luz de uma privação: a ação, "num sentido muito particular, preenche um vazio e vai do vazio ao pleno, de uma ausência a uma presença, do irreal ao real" (Idem, ibidem, p. 726). Assim, mesmo que toda ação humana se dê efetivamente no real, há uma imagem de irrealidade relativa à direção de nossa atenção - ele visa a um determinado fim, procura um certo objeto real que não encontra, o que a leva à imagem de uma

10 A ilusão do Nada é o centro da interpretação da filosofia de Bergson que encontramos em Presença e Campo Transcendental e está na raiz da aproximação entre o bergsonismo e a fenomenologia, que exploraremos mais adiante. Por ora, cabe examinar alguns de seus aspectos para que a noção de visão do real que sustenta a metafísica bergsoniana possa ser justamente avaliada. 
ausência. Se a psicologia nos dá a descrição do espírito funcionando para a prática, uma primeira explicação sobre a noção de ausência é de índole psicologista - o "sentimento de preferência" (Idem, ibidem, p. 733) que responde pelo lado subjetivo da ideia de uma abolição de tudo, isto é, a ideia de nada. Esse sentimento se conforma a um processo de substituição de objetos, o que é visado e o que é encontrado, supondo sempre um em lugar do outro. Toda tentativa de compreender a noção de nada, mesmo de uma ausência parcial, mostra que ela se dá sobre esse processo de substituição, e o objeto que respondia ao desejo será representado como ausente: "no lugar em que ele estava não há mais nada" (Idem, ibidem, p. 733). Uma representação que se forma à luz de uma espera e de uma decepção é, em qualquer de suas formulações, uma ideia prática. Nesse sentido, o mecanismo de formulação da ideia de Nada é o mesmo da ideia de Desordem, a Ordem não desejada.

A ideia do Nada tem outro alcance: ela impulsiona a ampliação da ilusão da estabilidade, pois, se o recorte de instantâneos do devir é um procedimento instituído pela ação vital, porque esta procura a fixação de campos estáveis e determinados, os futuros “objetos", esse processo é intensificado a partir da sua origem numa carência, da imagem de ausência que dirige a busca de presenças. Assim, a ação que vai do vazio ao pleno e recorta o real na busca da satisfação de carências é uma e a mesma, originando duas representações complementares, a imagem do vazio e o recorte de pedaços ou partes no contínuo. Nesse sentido, o real é identificado a um conjunto de objetos. A ação busca fins porque necessita tapar buracos; esses fins deverão ser constituídos de forma estável e fixa, devem aproximar-se do idêntico a si como imagem da permanência, justamente porque devem superar o vazio que vêm preencher. A implicação mútua entre as duas ilusões está fundada na origem comum e torna sua eficácia ainda mais operante. Bergson não poderia expressar essa ligação de modo mais claro: 
O desprezo da metafísica por toda realidade que dura vem precisamente do fato de que ela só chega ao ser passando pelo 'nada', e uma existência que dura não lhe parece suficientemente forte para vencer a existência e se colocar por si mesma. (Bergson 3, p. 729).

O resultado está estampado na história da filosofia: ao Ser jamais poderia ser atribuída uma existência psicológica ou mesmo física, ele necessita da identidade lógica. Também chamam a atenção os dois aspectos que envolvem a determinação da existência: ela se dá sobre um fundo vazio e busca o homogêneo, desconsiderando assim a plenitude e a heterogeneidade do real. A espacialização está em relação direta com o pensamento do ser imutável, e o estudo da sua origem como estrutura do entendimento será a chave da reposição da verdade. A exposição das ilusões é a confirmação de uma inclinação natural que define nosso acesso prático ao mundo e explicitá-la é um dos passos indispensáveis à obtenção do acesso teórico.

A filosofia de Bergson nada mais faz do que efetivar esse duplo movimento, mas circunscrevendo-o a cada campo de fenômenos estudado. A intuição da duração efetiva-se indissoluvelmente ligada à crítica da razão; ela é, num certo sentido, esse movimento de reflexão que liberta o devir ao nosso olhar. Compreender o pensamento de Bergson exige, portanto, acompanhar no detalhe a explicitação da crítica aos pressupostos inconscientes "primeiro no nível das consequências", isto é, nas obras sobre a liberdade, o dualismo e a vida, e então retomá-la, exatamente como a ordem dos livros nos expõe, no nível dos princípios. Os problemas filosóficos são repostos com a desconstrução das ilusões naturais ao entendimento: cada discussão de cada problema particular é também uma "recusa e denúncia de uma ontologia latente", cujo fundo consiste na "má concepção do tempo que determina o Possível como anterior ao Real" (Prado Jr. 12, p. 35).

A relação intrínseca entre a inclinação natural da razão e a ontologia que se institui silenciosamente no acesso prático ao mundo 
(passando a operar na ciência e na filosofia) é um dos aspectos do pensamento bergsoniano que será reavaliado por Merleau-Ponty em sua tentativa de superar a redução, tal como Husserl a prescreveu. Das suas primeiras considerações sobre a duração bergsoniana a uma revalorização da mesma, é a denúncia de uma ontologia da coisa ou do ser objetivo já presente em Bergson que transforma a postura excessivamente crítica do fenomenólogo. O pensamento da essência à luz da coisa-objeto é, como explica Barbaras, solidário de uma posição do ser determinado do mundo "a priori conforme as exigências da razão" que tem como pano de fundo a "atitude que consiste em abordar o Ser sobre o fundo do Nada" (Barbaras 1, p. 47). E eis o que é notável: trata-se de uma posição do mundo que está na raiz da atitude natural. Bergson teria o mérito de ter avançado o trabalho de explicitar o pressuposto e pressentir, desse modo, um novo pensamento do Ser, ainda que sua fidelidade ao vocabulário essencialista seja visada criticamente por Merleau-Ponty.

De todo modo, é extremamente fértil considerar adequadamente o nó das divergências e o campo de convergências entre o bergsonismo e a fenomenologia merleau-pontiana. A recusa da concepção de Ser lógico e imutável é compartilhada pelos dois autores, assim como o reconhecimento da sua origem pelo pressuposto do fundo negativo. Se Bergson opera a crítica da razão e reconhece a origem das ilusões racionais na naturalidade de nosso conhecimento, sua filosofia tem na redescoberta da essência do tempo a contrapartida da démarche crítica, porque já que estabelece, nas mais diversas situações investigativas, que o ser da duração é a mobilidade. Bergson define seu próprio processo filosófico como o que reencontra, para cada objeto estudado, aquilo que ele é propriamente ou "o que constitui a sua essência" (Bergson 3, p. 1394). Esse âmago do objeto atingido não poderia ser apreendido de fora, "sendo interior por definição". Assim, a intuição como conhecimento interior talvez ganhe algum esclarecimento ao se contrapor à intencionalidade da fenomenologia, a qual corresponde para Bergson precisamente à 
verdade do acesso prático ao mundo, acesso que deve ser superado e compreendido metafisicamente pela intuição da duração. A práxis institui uma distância que condiciona a objetividade; sua verdade é a constituição do horizonte, pedra de toque da descrição da consciência intencional dos fenomenólogos. Ao tratar filosoficamente da percepção como esse processo, a limpeza de terreno efetuada por Bergson na teoria da percepção pura, como veremos adiante, revela algo que é anterior ao próprio horizonte perceptivo. A verdade da visão que se trata de reencontrar precisa, assim, do trabalho reflexivo-crítico, e esse vínculo tem uma explicitação mais clara pela sua diferença com a redução, como afirma During: "ela não é um retorno às coisas mesmas, mas um trabalho ativo da inteligência sobre si mesma" (During 6, p. 863).

Por ora, fica claro que a intuição está referida a uma essência em formação, o devir, cuja positividade afasta Bergson da perspectiva filosófica de Merleau-Ponty num ponto fundamental. Assim, a neutralização do pressuposto ontológico do nada - que as duas filosofias, é preciso sublinhar, consideram um passo filosófico decisivo - teria, entretanto, consequências muito distintas nos dois pensamentos, e "a linha de demarcação a uma só vez estreita e profunda" (Barbaras 1, p. 49) entre eles estaria traçada no desdobramento da crítica do negativo. Se essa crítica em Bergson significa a "condução ao devir por oposição ao imutável", Merleau-Ponty reprovaria o fato de que ele não soube encontrar, mesmo seguindo o bom caminho, um "sentido de ser que inclui o negativo" (Idem, ibidem,). No entanto, como a própria oscilação do fenomenólogo a propósito da positividade do ser duracional bem o atesta ${ }^{11}$, é preciso ressaltar que, pela heterogeneidade inerente à duração, a positividade que lhe é

11 Para uma discussão profunda dessa avaliação oscilante na obra de Merleau-Ponty, ver a continuação do artigo de Barbaras, que recupera passagens de $O$ visível e o invisivel para ressaltar a importância da teoria das imagens de Matéria e memória no contexto da mudança da posição excessivamente crítica que encontramos na Fenomenologia da percepção. O fundamental é a tese de que o ser só se dá em seu aparecer parcialmente, ou a conclusão a que Bergson é conduzido pelo estudo da percepção: apreende, "no coração 
possível atribuir é radicalmente distinta daquela que é por ambos criticada, cujo modelo perfeito é dado pela positividade substancial. Assim, se a opacidade imanente à experiência é a marca do ser perceptivo de Merleau-Ponty, pois se trata do ser que se dá em sua própria ausência, sabemos que a apreensão do ser como movimento de diferenciação não autoriza atribuir a Bergson o retorno ao ser positivo da tradição, porque a transformação implica, de algum modo, passagem ao não ser.

Em todo caso, Bergson nos oferece, pelo viés crítico, indicações preciosas sobre outra conjunção que deve ser operada pelas intenções de seu método: trata-se também de reintegrar a visão direta e a reflexão, a sensibilidade e o raciocínio. A própria história da filosofia é avaliada por ele como desenvolvimento de distintos sistemas teóricos em torno de um mesmo núcleo, a negação da mudança, da sucessão verdadeira, do tempo e do movimento pela ingerência do conceito sobre o conteúdo originário da experiência. Não raro, o filósofo se refere à grande dificuldade que a tentativa de perceber a mudança impõe às nossas potências naturais de conhecimento, denunciando o "véu de prejuízos a descartar" (Bergson 3, p. 1367) ${ }^{12}$ para que se possa pensar e ver esse fenômeno capital - justamente o que deixamos de perceber no âmbito da especulação filosófica e do senso comum. Tal deve ser o esforço fundamental da metafísica, e seu eventual sucesso significará a efetividade da verdadeira filosofia, precisamente aquela que se realiza ao "voltar à percepção, sem renunciar às faculdades de concepção e raciocínio, conseguindo

do ser, uma negatividade que é a condição de sua aparição, ou antes, que é a própria aparição enquanto coincidência parcial, diferença de idênticos" (Barbaras 1, p. 56).

12 Os principais desenvolvimentos sobre essa dificuldade encontram-se bem sintetizados e explicados na conferência La perception du changement, da qual faz parte esse trecho citado. Ali encontramos a explicitação do vínculo intrínseco entre negação da mudança e desvalorização da experiência sensível que marca a origem da metafísica que tem na escola de Eleia seu marco inicial. Bergson chega mesmo a dizer que "A metafísica nasceu, com efeito, dos argumentos de Zenão de Eleia relativos à mudança e ao movimento" (Bergson 3, p. 1376). 
que a percepção se dilate e se estenda" (Idem, ibidem, p. 1369). ${ }^{13}$ Nessa medida, se a intuição da duração é uma visão, um modo de a duração aparecer, desde o início da obra de Bergson temos a explicitação de duas maneiras distintas e opostas desse aparecer: (1) por refração no espaço e (2) sem a mediação do espaço, isto é, o seu aparecer imediato, em que forma e conteúdo se efetivam e são mesmo apreendidos em sua efetivação.

Todos os problemas filosóficos derivam de se tomar como única forma do aparecer do tempo a sua apreensão no espaço ou como espaço. Mais correto é dizer que o equívoco reside em tomar como real uma forma do aparecer que é imaginária, criada artificialmente por nossa percepção e nossa inteligência no âmbito da ação. O estofo do real que se insinua na percepção, essa mutabilidade contínua e incessante, dá origem, por esse mesmo trabalho das faculdades, a uma representação confusa. As teorias filosóficas operam sobre essa representação e apenas a prolongam nos conceitos que circunscrevem a realidade do movimento e da mudança por atributos que, no final das contas, os negam. No próprio momento em que a filosofia inicia o seu percurso de apreensão e determinação do ser e de sua relação com o aparecer, ela parte dos conceitos já consolidados no campo prático e aplicados no trabalho científico - daí a justaposição de instantes como base do raciocínio matemático incorporado pela metafísica. A crítica das representações usuais do entendimento é, nessa medida, um instrumento para recuperar, no aparecer, o que é real, e esse trabalho se realiza como purificação, determinação dos elementos puros que se misturam na experiência concreta - essa mistura prática, ao ser transportada ao olhar especulativo sem nenhuma atenção e correção, torna-se confusão teórica. Assim, o que

13 A frase é elucidativa na medida em que apresenta a contrapartida do movimento que deu origem à metafísica grega, a constatação de uma certa "insuficiência" de nossas faculdades perceptivas que impulsionou a sua superação, necessidade de afastar o conteúdo da experiência sensível que somente nos "mostravam sombras projetadas pelas Ideias" (Idem, ibidem, p. 1368). 
a crítica faz é recuperar, rememorar e reapoderar-se daquilo que já está presente em toda e qualquer percepção, mas oculto em razão das finalidades vitais e sociais, as mesmas que dão origem ao trabalho perceptivo e o dirigem.

Trata-se, assim, de compreender como Bergson opõe duas visões do real, uma ilusória e outra verdadeira, e como estabelece meios para obter a intuição do espírito como algo que se faz e da matéria como o que se desfaz, ou seja, o conhecimento metafísico da duração real. Com isso, ele repõe ilusão e verdade noutro terreno, deslocando-o, de certo modo, da pura matriz da correspondência entre a representação e o real ou do equacionamento em termos de nomes, proposições e juízos. Falsidade e verdade se inscrevem na contraposição entre acesso prático e compreensão teórica, entre o registro da exterioridade do olhar que põe à distância e o da interioridade da visão que participa do ser em formação. A espacialização implicada nas démarches vitais não é uma representação falsa do real, mas a produção de uma ilusão sincera porque útil e inevitável, isto é, indispensável à vida. A falsidade configura-se no momento em que a filosofia arranja seus procedimentos de determinação do real sem atentar para essa distinção.

$\mathrm{Na}$ descrição das duas ilusões, Bergson indica o resultado da visão que dispensa a determinação intelectual: algo que nossa inteligência e os próprios sentidos nos mostrariam da matéria "se obtivessem sua representação imediata e desinteressada" (Bergson 3, p. 726). A mediação e o interesse são os elementos que se inserem entre nós e aquilo que vivemos. Como a ação é necessariamente voltada à matéria $\mathrm{e}$ ao futuro, exigindo a visada à distância e a determinação, o trajeto sugerido imediatamente pela descoberta do equívoco da tradição é a busca pela visão imediata de si por si, o retorno ao mundo interno como instância primeira em que a durée pode ser experimentada ou sentida para, em seguida, tornar-se parâmetro de reflexão. E esse retorno a si necessita da limpeza do terreno, da desconstrução das categorias já implicadas no estudo da consciência interna pelo senso 
comum, pela ciência e pela meditação filosófica. É por isso que a ideia de um retorno da consciência a seus próprios dados exige "um longo itinerário" permeado, como Bergson explicita, por uma série de "reflexões e análises críticas" (Idem, ibidem, p. 1256), pois é “árduo voltar a si para uma consciência que se acha mergulhada no universo da exterioridade e que somente aí encontra os instrumentos de sua consciência" (Prado Jr. 12, p. 89).

Um dos aspectos mais relevantes da modificação que se opera pela mediação dirigida pela ação é o pensamento do instante: de um contínuo, necessariamente suposto para que Bergson possa falar de "vistas instantâneas", a inteligência está limitada a recortar imobilidades instantaneamente tomadas, isto é, do devir da matéria os sentidos e a inteligência recortam partes fixas por "saltos". A mesma operação, aliás, é feita pela consciência em relação à vida interior (a seus próprios momentos) quando ela "se deixa regular pela inteligência"; tanto num caso como no outro, temos instantes destacados da duração, segundo nossos interesses e necessidades. Está configurada a segunda ilusão da razão examinada por Bergson: no conhecimento especulativo sobre a natureza do real que não se libertar dos pressupostos da ação, falaremos de devir e de duração, mas estaremos pensando em outra coisa, pois estaremos dirigidos pela crença na possibilidade de "pensar o instável por meio do estável, o movente pelo imóvel" (Idem, ibidem, p. 726). Tal ilusão refere-se, sobretudo, à oposição entre fluidez e instantaneidade, entre uma continuidade em transformação e uma série de cortes ou quadros instantâneos e fixos nela operados. Na continuidade movente da matéria, na vida heterogênea e dinâmica do espírito, o devir vira forma fixa, a duração vira associação de instantes.

No caso da vida do espírito, a interioridade psicológica é representada como justaposição de momentos fixos, de partes exteriores umas às outras, uma imagem da vida interior que procura recompor o seu movimento incessante e sua transformação contínua pelo desdobramento em partes espacialmente delimitadas. Essa é, afirma 
Bergson em diversas ocasiões, a concepção associacionista do espírito, uma "recomposição artificial da vida consciente" (Idem, ibidem, p. 1255) onipresente no âmbito científico e nos diversos sistemas filosóficos. É esta a imagem da vida mental decorrente da exteriorização, da extração de campos de estabilidade, estados determinados, objetos isolados ou isoláveis, imagens ou ideias condicionadas pela forma espacial. O associacionismo é a única explicação condizente com a consciência figurada em inteligência e dirigida, sobretudo, pela linguagem. Mais que isso, o associacionismo está intimamente ligado à representação do tempo como linha ou justaposição de pontos, fundamento da consideração do tempo como forma a priori da sensibilidade na Estética Transcendental de Kant. Essa representação do desenrolar dos eventos em uma linha temporal, isto é, a própria noção de tempo como linha mensurável e dotada de partes ou unidades pontuais (uma representação geométrica do tempo), foi tomada como sua verdade e conduzida pela história da filosofia como imagem fiel da temporalidade. Não poucas vezes Bergson define os sistemas filosóficos por seu ato fundador e comum: o desviar-se da duração que os levou a "tratar o espaço e a duração como coisas do mesmo gênero" (Idem, ibidem, p. 1256). Mais explicitamente, a concepção associacionista do espírito nada mais é do que o resultado da transposição desse ato cognitivo compartilhado entre o senso comum e a ciência para o estudo da interioridade psicológica. Os estados de consciência serão recortados e associados em linha, em suma espacializados. Essa concepção tem um vínculo estrito com a determinação do tempo como forma da consciência ${ }^{14}$, meio em que seus estados se desdobrariam em sua evolução pensada como justaposição. A identificação entre espaço e tempo como formas da

14 O vínculo direto entre a psicologia associacionista e a teoria do conhecimento é apontado por Bergson ao final da primeira introdução de La Pensée et le Mouvant. Para voltar à experiência e recuperar a visão direta e imediata de seus dados, é imprescindível romper com uma certa concepção psicológica, a associacionista, em concomitância com a recusa de uma filosofia geral, o kantismo. 
sensibilidade, diferenciadas apenas por uma substituição de nomenclatura, a justaposição no espaço virando sucessão no tempo, torna compreensível a afirmação de Bergson sobre aquilo que se trata de descartar para que a reflexão filosófica atinja seus verdadeiros objetivos: associacionismo e kantismo.

A descoberta dos equívocos relacionados à representação do tempo (comum, científica e filosófica) ilumina por si mesma o caminho a ser seguido. Se o erro da inteligência operando sem crítica consiste em desviar-se da duração, equívoco inevitável dada a sua função de "presidir as ações na busca de seus fins" (Bergson 3, p. 747), resta encontrar um modo de "instalar-se de imediato na duração" (Idem, ibidem). E isso somente será possível na medida em que os prejuízos do conhecimento racional sejam afastados, na medida em que a consciência reflexiva puder evitar as ilusões naturais da inteligência. A primeira delas, pensar o movente por meio do imóvel, transformando assim a duração em momentos que se acrescentam uns aos outros, tem um objeto privilegiado para abrir o caminho de sua dissipação: o exame da vida do espírito, o estudo dos dados da consciência psicológica. Porém, trata-se de um exame impulsionado por um querer, uma atitude da própria consciência que implica intenso esforço de afastar as inclinações naturais e os conceitos por elas já misturados ao saber de si. Esse esforço possibilita um aparecer da duração, um modo de perceber o tempo, ou melhor, a duração nada mais é do que o próprio "tempo percebido como indivisível" (Bergson 2, p. 907). Se a filosofia pergunta sobre o "que é a duração", sobre aquilo que "a ciência elimina”, essa questão identifica-se com a pergunta sobre o aparecer. Ser e aparecer estão vinculados, e perguntar sobre o que é a duração é, a um só tempo, responder à indagação:

Como a duração apareceria a uma consciência que não quisesse senão vê-la sem medi-la, que a apreendesse então sem detê-la, que se tomasse enfim a si mesma por objeto e que, espectadora e atriz, espontânea e 
reflexiva, aproximaria, até fazê-las coincidir, a atenção que se fixa e o tempo que escapa? (Bergson 3, p. 1255)

A resposta é uma experiência, precisamente a de um modo de ver o ser do tempo, de delimitar um aparecer da duração à consciência, um como, uma manifestação. Trata-se de um encontro entre o conhecimento e o tempo, entre um tipo de consciência (porque uma visão) e a duração, visão da qual alguns aspectos são explicitados: em primeiro lugar, a duração pode ser apreendida por uma visão especial, que depende de uma vontade, o querer ver sem medir; em segundo lugar, essa consciência efetivaria uma operação especial, uma apreensão que não detém (mesmo que haja quase uma oposição entre apreender e não deter). Mas, ainda nos indica a questão por ele formulada, a consciência que quer ver sem deter, aquela à qual a duração apareceria, é a mesma que se toma como objeto - ela é em alguma medida reflexiva e, portanto, espectadora e atriz. A consciência age e vê, é o ver do fazer, ou antes, do fazer-se. A duração que apareceria à consciência é a própria consciência: a consciência da duração e a duração da consciência estariam identificadas nessa visão.

\section{A duração interna e sua presença pura ao sujeito: totalização contínua e heterogênea}

A primeira formulação da duração surge no Ensaio sobre os dados imediatos da consciência, o estudo da presença interna pelo exame crítico das noções de intensidade e multiplicidade. Trata-se do encontro com "nosso eu que dura", um reaprender da nossa vida interior através do afastamento dos prejuízos e conceitos advindos da operação de justaposição de estados conscientes numa forma imaginária - o tempo espacializado. O trajeto de análise do sujeito psicológico encaminha um aparecer da duração pela abstenção dos processos de espacialização, o que significou para Bergson superar 
a concepção associacionista do espírito, uma "recomposição artificial da vida consciente" (Bergson 3, p. 1254) da qual comungavam a maior parte dos cientistas e filósofos. Há uma atitude da consciência que possibilita a intuição, uma "longa série de reflexões e análises" (Idem, ibidem), isto é, de atos filosóficos, sobretudo críticos, que permitem o contato com a temporalidade. Se o campo da práxis produz uma "ontologia latente", é possível iluminar esse pressuposto pela reflexão colada aos fatos: aplicados ao entendimento pelo exame minucioso de seus conceitos, os processos de análise crítica acabam por denunciar o afastamento do terreno dos fatos, a partir do qual opera a consciência reflexiva. No caso da interioridade psicológica, isso significa denunciar a representação ilusória que é o associacionismo pela dissociação de dois conceitos que operam no saber: o de grandeza intensiva, cujo exame revela a verdadeira intensidade de estados conscientes, tais como nossos sentimentos profundos; e o de tempo homogêneo, forma na qual a multiplicidade interna concreta se desdobra na sua recomposição espacial.

O exame da experiência interna que marca o princípio sobre o qual se funda a filosofia de Bergson revela a autoestruturação progressiva e qualitativa de conteúdos psicológicos, uma apreensão obtida mediante a crítica da noção de grandeza intensiva e pela separação, nessa representação, do que é efetivamente experimentado e do que se mistura pela imaginação espacializadora. O que Bergson faz é constatar, na experiência psicológica, o que vem dela e o que vem de "outro lugar" - exatamente a forma espacial ou o meio vazio e homogêneo que não pode, de modo algum, ser confundido com a heterogeneidade. Ao demonstrar, na base de toda quantificação, o papel do espaço, Bergson estipula que a grandeza não é um aspecto diretamente presente na experiência interna, mas uma construção a partir dela. Ele atribui assim à multiplicidade concreta dos estados de consciência imediatamente vividos um valor de existência: há uma experiência efetiva do múltiplo não quantificável que se manifesta como progressão qualitativa e expressa fielmente o que 
se passa em nossa interioridade, uma vez que a consciência se isole do mundo exterior e "volte a ser ela mesma". O trabalho de volta a si é identificado a um "vigoroso esforço de abstração" (Bergson 3 , p. 67), cujo resultado essencial é o encontro com a duração, em primeiro lugar a duração consciente em sua forma pura, a "forma que toma a sucessão de nossos estados de consciência quando nosso eu se deixa viver" (Idem, ibidem). Encontro que significou também a descoberta do caminho para superar a representação prática do real, a via para evitar os prejuízos e a mediação de formas ou conceitos a priori no contato teórico com a realidade: deixar-se viver significa, mais que tudo, abstrair-se de separar momentos da duração em partes, abrir mão de impor a forma da exterioridade recíproca forma espacial - ao conteúdo da experiência consciente. Bergson é ainda mais explícito ao descrever base dessa atitude teórica: não há necessidade, para reencontrar a vida do espírito em sua manifestação direta, de "absorver-se inteiramente na sensação ou na ideia que passa" (Idem, ibidem, p.67), o que significaria, para o eu, o mesmo que parar de durar. Não se trata, portanto, nesse encontro, de uma fusão indiferenciada entre o sujeito e sua experiência consciente, de uma introspecção "na qual o sujeito e o objeto estavam confundidos e o conhecimento era obtido por coincidência" (Merleau-Ponty 9, p. 90), uma definição da interioridade como impressão. Ao contrário, a vida interior apreendida pelo esforço de acesso aos seus dados imediatos revela-se como autototalização imanente, como constituição de um todo por diferenciação imanente.

O que o filósofo vê ao evitar justapor estados de consciência num meio homogêneo é o mesmo que vemos quando nos lembramos das notas de uma melodia "fundidas conjuntamente", e "a vida interior é essa própria melodia" (Bergson 3, p. 67 e p. 1261) — retomaremos adiante dimensões dessa metáfora reveladora em todos os sentidos. $\mathrm{Na}$ apreensão da vida consciente por um esforço consciente de não justaposição, o sujeito pode lembrar-se de seus estados sem representá-los como pontos no espaço, sem esquecer os estados anteriores 
ao pensar nos posteriores. A representação - a de uma visão direta e imediata dos dados da consciência pela consciência - assim obtida é a de "um conjunto cujas partes, ainda que distintas, penetram-se pelo próprio esforço de sua solidariedade" (Idem, ibidem, p. 68). Uma solidariedade tão íntima que qualquer modificação numa de suas partes significará, para a consciência, uma mudança qualitativa no todo. A duração concreta do eu consiste, assim, na constituição de uma totalidade desse tipo e a sua representação fiel, visão direta ou acesso imediato, se dá no momento em que a consciência é capaz de viver esse conteúdo em formação, por uma lembrança de seus estados que não insista em separá-los e justapô-los, numa palavra, em tomá-los como coisas no espaço. Lembrar dos estados por esse esforço impõe à consciência uma imagem representativa em que heterogeneidade e solidariedade, multiplicidade e unidade, coexistem. Mais que isso: multiplicidade e unidade de partes em formação, num processo de sintetização imanente que nos impede de considerar o dado imediato como impressão muda ou coincidência inefável.

Assim como o campo fenomenal de Merleau-Ponty, o imediato é também dotado de certa significação imanente, suas partes se coproduzem sob o horizonte do todo, seu sentido é secretado pela própria sucessão. A duração pura, cuja representação somos capazes de atingir numa intuição enquanto visão não mediada pela forma espacial, não se revela como "mundo interior tenebroso" (MerleauPonty 9, p. 90), mas como conteúdo em constituição, cuja unidade é garantida pela "penetração mútua, organização íntima de elementos" nos quais a totalidade está presente e se expressa. O núcleo do encontro com a manifestação direta dos estados de consciência reside no exame dos sentimentos profundos no primeiro capítulo do Ensaio. A experiência estética revela ao sujeito um contato com o objeto em que se dissipa a separação ou a distância entre eles. Ao examinar a própria experiência do sentimento da graça, o eu pode compreendê-la como movimento de diferenciação qualitativa, progresso que se expressa em figuras dominantes cuja relação é interna. 
Sua imbricação recíproca e sua sucessão qualitativa refutam a interpretação quantitativa que vê no sentimento uma unidade homogênea a si, acrescentando-se a si justamente a visão comum e científica do aumento de intensidade dos estados de consciência.

A descrição do sentimento tal como ele aparece à consciência em sua constituição traz à tona uma multiplicidade em formação, um múltiplo como totalidade em progresso, isto é, uma experiência em que momentos distintos uns dos outros se sucedem na medida em que são interiores uns aos outros - são diferentes sem ser exteriores entre si. Vimos, em outro momento ${ }^{15}$, como as figuras estão virtualmente presentes umas nas outras, assim como a figura final vem explicitar o sentido inicialmente contido na primeira manifestação do sentimento. Essa figura final, no caso do gracioso, é justamente a superação imaginária da separação entre aquele que vê e aquilo que vê, o espectador de um bailado e o movimento executado, como se o objeto se constituísse pelo sujeito e este tivesse um conhecimento total e absoluto do objeto em formação - um conhecimento de dentro, interior ao objeto, uma espécie de "penetração imaginária”. ${ }^{16}$

15 Uma análise detalhada da descrição dos sentimentos profundos é um dos momentos centrais do livro e explicita essa relação interna entre os momentos do tempo em sua apreensão como movimento de totalização. As consequências dessa análise para a crítica bergsoniana do tempo homogêneo de Kant podem ser encontradas em Morato Pinto 11.

16 À consideração externa do objeto (ou mediada pela forma da exterioridade), própria ao conhecimento analítico, Bergson contrapõe uma consideração do objeto sem a finalidade da comparação, um olhar que procura captar o objeto no que ele tem de único e singular, e que só poderia se efetivar como intuição. A visão direta do objeto, coincidência ou simpatia, significa a apreensão de seu efetivar-se no tempo, do seu desenrolar-se. Isso impede que a relação estabelecida entre sujeito e objeto na intuição possa ser definida como mera fusão, já que um momento do devir remete necessariamente à sua continuação. A temporalidade de um objeto a ser conhecido é sempre a relação entre seus momentos interiores uns aos outros - a captação intuitiva de uma dimensão qualquer do real, a experiência efetiva apreendida de dentro é sempre a de uma relação interna entre suas fases distintas e heterogêneas. Assim, a visão interior aproxima-se da relação expressiva cujo papel na experiência é, para Merleau-Ponty, totalmente desprezado pela investigação do Ensaio. 
Não custa insistir: o papel da totalização encontrada na vivência interior do tempo é o diferencial em relação à absoluta realidade do conteúdo vivenciado: não há como compreender que a "intuição da duração me coloca em presença de um vivido universal" (VieillardBaron 15, p. 78) sem alcançar aquilo que pode ser distinguido da pura apreensão subjetiva ou meramente individual. A relação entre os momentos dos sentimentos profundos indica um prolongamento mútuo e uma implicação, em que as partes expressam uma essência, cabendo ao trabalho do Ensaio delimitar o estatuto filosófico dessa vivência, delimitação explicitada na teoria da multiplicidade. A contraposição que funda a distinção entre duração e espaço é o estabelecimento da diferença irredutível entre a multiplicidade do número e a multiplicidade interna, distinção que se efetiva no coração do Ensaio, o segundo capítulo. Ali, para desfazer uma confusão que invade nossa compreensão do conjunto da vida psicológica e acaba por corromper "nossas representações da mudança exterior e da mudança interna, do movimento e da liberdade" (Bergson 3, p. 51), Bergson nos fornece, como ressalta Worms, "critérios estruturais irredutíveis que opõem duas espécies de multiplicidade, e através delas duas espécies não somente de fundamento cognitivo ou subjetivo, mas talvez mesmo de tipos de ser ou de realidade" (Worms 18, p. 44). Se a multiplicidade concreta da vida interior não é a de uma justaposição, é justamente na medida em que nada no esquema da multiplicidade numérica pode se aplicar ao tipo de fusão ou relação interna cuja experiência é revelada pelo estudo da interioridade. Anos depois de ter publicado o Ensaio, Bergson expõe numa célebre conferência as principais etapas de sua introdução à metafísica, retomando sua descoberta inicial da seguinte maneira:

Se eu me concentro da periferia para o centro, encontro algo totalmente diferente: por sob esses cristais bem recortados e esse congelamento superficial, uma continuidade de escoamento, uma sucessão de estados dos quais cada um anuncia o que se segue e contém o que o precede; 
enquanto eu os vivenciava, eles estavam tão solidamente organizados, tão profundamente animados de uma vida comum, que eu não saberia dizer onde um deles acaba, onde começa o outro. Na verdade, nenhum deles começa nem acaba, mas todos se prolongam uns nos outros. (Bergson 3, p. 1397, grifo meu)

A duração pura surge em sua plenitude ao cabo da análise da multiplicidade interna como verdadeira sucessão. A volta ao terreno dos fatos na primeira etapa do bergsonismo significa adesão à temporalidade que a descrição do aparecer manifesta de si mesma, quando acompanhada no seu fazer-se imediato - isto é, sem pressupostos externos que a dirijam. Na análise dos dados imediatos da consciência, essa manifestação se expressa adequadamente por meio da imagem da melodia: o eu que se esforça em deixar-se viver, que abdica da separação artificial da vivência de seus estados em momentos fixos ou partes nitidamente delimitadas, encontra um todo em formação, no qual ele toma parte ao organizar seus estados consigo, participando interiormente de uma progressão da mesma ordem que a lembrança das “notas de uma melodia” (Bergson 3, p. 67) 17, cujo principal aspecto a ser notado é a totalidade não totalizada que lhes dá sentido. A relação entre a totalidade em formação e suas fases é dinâmica, na medida em que, a cada nota que se acrescenta, ela se modifica sem, entretanto, se

17 A metáfora da melodia é recorrente na obra de Bergson. O “efeito de solidariedade" por ela ilustrado é também a marca do ser vivo. Ela é associada com os termos "lembrar", "lembrança", pois perceber as notas umas nas outras é rememorá-las. Assim, o estudo da memória na obra seguinte já está anunciado nas "definições" descritivas da duração. Mais adiante, explorando o exemplo das oscilações de um pêndulo, ele nos oferece a mesma imagem da representação direta do efeito sensível em nossa consciência: “(...) ou eu as perceberei uma na outra, penetrando-se e organizando-se entre si como as notas de uma melodia, de modo a formar o que chamamos uma multiplicidade indistinta ou qualitativa, sem nenhuma semelhança com o número: eu obterei assim a imagem da duração pura" (Bergson 3, p. 78). 
desintegrar - ela é uma continuidade indivisível e, por isso, o percurso do Ensaio pode ser dito descoberta da substancialidade ${ }^{18}$ do eu:

(...) a experiência estava ao alcance de todos; e aqueles que quiseram fazê-la não tiveram dificuldade em se representar a substancialidade do eu como sua duração mesma. É, dizíamos nós, a continuidade indivisivel e indestrutivel de uma melodia em que o passado entra no presente e forma com ele um todo indiviso, o qual permanece indiviso e mesmo indivisível a despeito daquilo que a ele se acrescente ou mesmo graças a isso. (Bergson 3, p. 1312, grifo meu)

Isso significa que o trabalho crítico que faz a consciência retornar ao contato com o seu conteúdo prepara a apreensão dos dados em autoprodução e estamos, então, diante de um contato e de um fazer-se. Assim, a discussão em termos de dissociação analítica dos conceitos oriundos da mistura própria à práxis, na medida em que libera a consciência de sua visão, limitada à função vital (pela qual ela seleciona, deseja, recorta e age), abre o caminho para que o ser encoberto pela relação pragmática seja exposto ao seu olhar. No exame da duração vivida pela consciência atual, o que se revela é a verdade do presente como horizonte em que a consciência tem acesso a um ser não mais estático, já que "no presente algo se produz para a consciência, que é a consciência da lei interna de sua produção" (Prado Jr. 12, p. 65). Em outros termos, pelo movimento polêmico - "preparação dialética para a experiência direta do Ser" (Idem, ibidem, p.63) - o que se atinge mediante um encontro é a experiência como Presença do real à consciência.

Já no Ensaio, ainda sem nenhuma referência à intuição como método, a multiplicidade interna e qualitativa dos estados de consciência se

18 Bergson não abandona os termos ligados à substância, mas trata de modificar o seu sentido: aqui e em outras passagens, a "substância" nada mais é do que a conservação, a persistência no ser. Haveria bastante interesse em fazer a contraposição entre os sentidos do termo nas metafísicas da tradição — infelizmente não é o caso aqui. 
mostra à consciência numa "adequação absoluta", como sucessão verdadeira, isto é, prolongamento de momentos uns nos outros à luz de um sentido, que os unifica virtualmente e pelo qual eles se reportam uns aos outros, sentido que pode ser dito sua essência. Assim, podemos retomar os termos de Marquet ao apontar o que considera a intuição central e diretriz do Ensaio: a apreensão do tempo como um "plano em que o todo se re-encontra, se re-presenta, se re-percute em cada parte" (Marquet 8, p. 78). O eu faz parte desse todo que ele mesmo vivencia ou presencia, está nele integrado e participa, então, de uma solidariedade que permite compreender a interioridade psicológica se fazendo como um em-si, ou ao menos considerar o contato obtido como acesso a um objeto que não se dá à distância, mas não é criado ou projetado pela consciência - um objeto solidário a uma totalidade e ao qual o sujeito se integra na sua presentificação. Há participação na e visão da integração, há presença real e efetiva do ser ao qual a consciência está integrada, mas que não se confunde com ela.

Ocorre que a apreensão da duração interna como sucessão verdadeira é efetivada como reflexão, movimento da consciência tomando a si mesma como objeto, cujo resultado dessa reflexão é a visão de si como "fazer-se". Entre a consciência e sua duração, não há mais a rede de conceitos e o véu da espacialização impedindo que seus estados apareçam em sua multiplicidade concreta. Esse aparecer do conteúdo consciente ao eu que se delimita por essa consciência identifica-se a pensar no próprio ritmo desse aparecer, o "pensar em duração" que acompanha a temporalidade do objeto em sua gênese. $\mathrm{O}$ exame e a determinação de suas consequências evitam que se represente o conteúdo consciente como estados delimitados e exteriores acrescentando-se a si - a representação associacionista da vida do espírito. A temporalidade do conteúdo da consciência torna-se acessível por esse contato preparado pela démarche crítica, e enquanto relação solidária a uma totalidade que se repercute em suas partes, a consciência da duração é o mostrar-se da duração da consciência. Daí a consciência, de início subjetividade prática que recorta o mun- 
do por suas necessidades - processo que caberá a Matéria e memória analisar e, dessa forma, ampliar o campo da Presença a si da duração - converter-se em atriz e espectadora da temporalidade em ato, isto é, nesse movimento teórico que é conversão, transformar-se em consciência intuitiva, "introdução ao mostrar" (Prado Jr. 12, p. 63). Não se trata mais da representação da interioridade psicológica, e sim do acesso à sua Presença - intuição já, ainda que Bergson não se refira ali a considerações de método. Estamos tratando assim da "introdução à metafísica", passagem do eu prático ao eu teórico pela recuperação das potências originárias que o constituem e que se ocultam pelo movimento da existência.

Há alguns problemas aos quais essas considerações nos conduzem. Em primeiro lugar, o movimento de totalização ou integração surge no Ensaio como verdade da sucessão na interioridade psicológica, mas não se esclarece nesse percurso como se dá esse movimento, que tipo de instância responde por ele, se há como discernir conteúdo que se totaliza e ato de totalização etc. Assim sendo, o processo não é ainda explicitado. Bergson cita, quando tece breves considerações sobre o conceito de movimento, um ato de síntese mental, legando a suas reflexões posteriores o esclarecimento e a exploração desse ato. Na realidade, a conjugação entre um ato imanente à duração e suas formas assumidas em diversos momentos da nossa experiência é o que se trata de procurar, o que é necessário compreender. Conforme explica Worms, a confusão prática implicada em nosso viver consiste, sobretudo, em ocultar "o ato que assegura a conservação real desses momentos do tempo (...) ato que faz da sucessão uma continuidade e uma vida, não somente a sucessão de alguma coisa, mas a duração de alguém" (Worms 19, p. 10).

Em segundo lugar, a totalização que permite falar de um objeto não constituído ou projetado pela subjetividade, mas ao qual ela mesmo está integrada ou em integração na verdade de seu presente, está confinada a um domínio da realidade - a interioridade do sujeito. O problema da duração da matéria não está colocado, mas 
está prenunciado, sobretudo no estudo final sobre a liberdade que fecha o Ensaio e é mesmo o objetivo de todo o percurso do livro. O ato livre como expressão da totalidade da vida psicológica se define hipoteticamente sem ainda dispor das condições concretas de possibilidade de efetivação - ele tem que se inserir no mundo: é preciso encontrar na matéria sua dimensão espiritual, sua duração, único meio de fundar a unidade entre a subjetividade e seu meio provando que a liberdade pode se inserir no campo da necessidade. O problema da matéria está delineado e, com ele, o tema do dualismo, pois se os sistemas materiais que parecem tender à coisa espacial existem ao lado das consciências, então "o filósofo, que não quer deixar nada de lado, é efetivamente obrigado a constatar que os estados de nosso mundo material são contemporâneos da história de nossa consciência. Como esta dura, é preciso que eles se liguem de alguma forma com a duração real" (Bergson 3, p. 1261).

Finalmente, se o movimento de totalização é referido, ainda que de modo alusivo, aos termos "lembrar-se" e "rememorar-se", o título do segundo livro de Bergson está anunciado. Mais que isso, considerando a relação entre teoria e prática que delineamos acima, Matéria e memória é o momento-chave para sua compreensão, pois a subjetividade que se constitui na relação com o mundo pela efetividade da vida será o ponto de partida e núcleo da solução bergsoniana para o problema do dualismo entre espírito e matéria.

\section{Percepção, ação e materialidade: da matéria ao espírito pelo corpo e pela memória}

A inserção prática no mundo tem um processo originário, a percepção, cuja redescrição em termos temporais constitui um dos principais objetivos de Matéria e memória. Ao retomar o problema do dualismo entre corpo e espírito, Bergson estuda os processos conscientes, incorporando a relação entre interioridade e exterioridade. $\mathrm{Na}$ verdade, o estudo que se inicia por uma análise da percepção é 
o desenvolvimento de uma nova posição do problema do dualismo, com a passagem da psicologia à metafísica. Antes tomados como sujeito e objeto, representação e matéria, ideia e coisa, os termos da tradição filosófica são renovados, já que a redescrição operada por Bergson identifica-se a tratar em termos de tempo "as questões relativas ao sujeito e ao objeto, à sua distinção e à sua união" (Bergson 3 , p. 218). Toda a reposição do problema e de seus desdobramentos gira em torno da análise do processo consciente por excelência, a inserção de lembranças numa percepção pela qual reconhecemos os objetos, ou seja, a rememoração ou representação propriamente dita. Trata-se de discriminar teoricamente os elementos que nela se misturam — percepção e lembrança — para bem apreender sua ligação com duas totalidades que figuram como as dimensões ontológicas que devem ser relacionadas: o universo das coisas (a matéria) e o conjunto de lembranças de uma vida individual, de uma história pessoal conservada (o espírito).

Esse estudo tem na teoria da percepção uma base em que todas as suas direções são definidas, uma análise dissociativa fundada na constatação inicial de um campo de imagens atravessado pela vida, delimitando uma gênese ideal do sujeito e do objeto à luz de um campo que lhes é anterior, o campo de imagens que funciona como "fundo transcendental na constituição da subjetividade" (Prado Jr. 12, p. 134). A posição do problema do dualismo em termos de imagens é a estratégia para neutralizar os pressupostos conceituais que dirigem as formulações correntes, cujos representantes esquemáticos são o realismo e o idealismo. Nessa medida, a teoria da percepção consiste num momento paradigmático do pensamento bergsoniano, em que podemos detectar claramente um processo reflexivo de depuração da experiência, isto é, a "purificação da experiência como um processo de aprofundamento" (Idem, ibidem, p. 163). Ela oferece, assim, o modelo para compreendermos como uma análise dissociativa e ideal é condição da efetiva apreensão do real em ato, da "continuidade indivisa" 
dada numa intuição pura que subjaz à cristalização aparente dos fenômenos ou fatos comumente acessados pela consciência.

Em outros termos, acompanhamos o trajeto pelo qual Bergson pôde construir uma teoria que separa de direito os elementos presentes na experiência concreta: a percepção pura como contato imediato com a matéria, e a memória pura como totalidade não representável de lembranças conservadas por si mesmas (o próprio espírito) - para então compreender o presente temporal da consciência à luz do papel do corpo "sempre orientado pela ação, limitando a vida do espírito" (Bergson 3, p. 316). O percurso explicita, desse modo, a complexidade do manejo da intuição como método de divisão, conforme Deleuze enfatiza em seu inventário das regras do método bergsoniano: "Trata-se sempre de dividir um misto segundo suas articulações naturais" (Deleuze 5, p. 14), uma divisão do fato em suas "tendências de direito", o que assegura sua convergência com a "análise transcendental" (Idem, ibidem).

A neutralização das teses conflitantes que a filosofia lega ao século XIX, sobretudo aos psicólogos, envolve a consideração da força de agir do um corpo inserido, enquanto imagem, no campo de imagens. Esse corpo é especial, é a explicitação do ser vivo e da individualização que o define: ele é também um "corpo-próprio". A suposição que restará por esclarecer encaminha a obra seguinte de Bergson e o final de um ciclo que tem na refundação do evolucionismo o seu auge: é o estudo da vida que completará a metafísica dos dois livros cujos aspectos aqui analisamos. Interessa-nos, sobretudo, acompanhar como a suposição da vida atravessando o campo permite a construção de uma teoria da percepção pura, justamente a redescrição do processo de endosmose entre sujeito e objeto que, no Ensaio, aparecia timidamente. Ali, vimos que o instante e a simultaneidade eram os pontos cruciais tanto da efetivação da experiência mista (como determinação de nossa condição humana) quanto dos equívocos teóricos virtualmente implicados nessa determinação, já que o instante respondia pela relação entre 
interioridade e exterioridade, e implicava a ilusão da descontinuidade, aparecendo aos olhos da consciência reflexiva como se fosse a representação fiel de seus próprios estados, tomados assim como partes extensas que se acrescentam a si na vida interior.

A teoria da percepção pura contrapõe-se, passo a passo, ao modo como a teoria da representação é construída na tradição filosófica, sobretudo pelos sistemas realista e idealista. Há duas dimensões das concepções usuais que são visadas criticamente por Bergson e à luz das quais sua hipótese mostra grande avanço: a ideia de que "representação" e "coisa" são definidas exatamente pelo que falta na outra, consistindo em termos exteriormente recíprocos e cuja união torna-se quase impensável; e a tese de que nossa percepção concreta é, de início, uma sensação subjetiva e interior cuja projeção na exterioridade formaria a representação do mundo e seus objetos extensos. Isso quer dizer que a hipótese delineada por Bergson tem uma motivação: a necessidade de evitar os erros impregnados nas sucessivas posições do problema da representação. ${ }^{19}$ Ao simplificar as condições em que a percepção concreta se dá, afastando as impurezas que a ela se misturam, Bergson pode dar conta de uma dimensão da

19 Os equívocos correntes são em parte comprometidos e agravados, por um lado, pelas afecçôes, modificações interiores ao corpo e nele sentidas e, por outro, pelas lembranças, entidades que formam a história de um sujeito e, por isso mesmo, são por definição subjetivas ou individuais. Assim, afecções e lembranças respondem por parte da confusão filosófica que vê na percepção a exteriorização de sensaçôes inextensas. A teoria da percepção pura é o marco inicial e a condição de esclarecimento dos processos mistos porque permite a consideração passo a passo das impurezas, sendo completada por uma teoria das afecções, dor e prazer redefinidos como sinais da pré-espacialidade interna ao corpo e, posteriormente pela teoria da memória, que traz o espírito ao terreno da análise. O trajeto de Matéria e memória expõe o modo como os fatos comuns e experimentais, normais e patológicos, devem ser abordados a partir de uma análise prévia. A teoria da percepção pura é indispensável ao objetivo geral do capítulo sobre o papel do corpo e assim pela ligação interna entre as etapas do livro: para fazer retornar o problema do dualismo ao terreno dos dados imediatos, é preciso que o trabalho negativo prepare "a leitura dos fatos da psicofisiologia" (Prado Jr. 12, p. 137). Tal leitura trará as comprovações da hipótese elaborada no momento transcendental, na separação ideal das partes ou tendências que formam a representação. 
percepção que permite toda a continuidade do livro, isto é, recuperar o que a tradição filosófica desconhece, "o ato original e fundamental da percepção, esse ato, constitutivo da percepção pura, pelo qual nos colocamos de início nas coisas" (Bergson 3, p. 71).

Todo o primeiro capítulo do livro responde pelo viés crítico da obra, ou ao menos pela determinação das variáveis do trabalho negativo. Seu resultado consiste basicamente em encontrar os dados incontornáveis sem os quais não é possível a descrição do aparecer, o que é fundamental: não se trata, pelo menos ainda, de elaborar indutivamente uma hipótese que possa rivalizar com os cientistas do paralelismo, nem de apresentar teses ontológicas afirmativas. Estamos no momento de repor o problema em novos termos, as imagens, e o que Bergson enfatiza ter conseguido é "formular os dados que nenhuma teoria da percepção pode dispensar" (Idem, ibidem, p. 37). O campo de imagens corresponde, nesse âmbito, à representação virtual do todo, da totalidade dos objetos no mundo, ou seja, das imagens percebidas. A percepção está primeiramente no mundo, como perceptibilidade, cujo fundamento é a relação contínua entre as imagens, a atualização dessa potencialidade é efetivada pelo ser vivo. ${ }^{20}$ Apenas pela descrição da ação especial desse corpo, distinguindo então, através de critérios objetivos, dois tipos de ação que serão remetidos a dois universos ontológicos: a ação necessária da matéria e a ação consciente ou virtualizada do espírito (ação possível e nascente, segundo as determinações que o percurso do livro tratará de esclarecer) —, Bergson pode mostrar a necessidade intrínseca da

20 As imagens estão em relação ininterrupta mostrando todas as suas faces umas às outras sem exceção - daí a inconsciência e a necessidade que marca um ponto qualquer desse campo. A relação com um contato ou com uma visão possível é uma necessidade a que "nenhuma teoria da matéria escapa", e a percepção da matéria se diferencia da matéria em si porque obscurece todo o resto do campo que no momento não interessa ao corpo — ela retira da totalidade uma parte, definida mesmo como um "quadro" ou "invólucro". Esse retorno da percepção à imanência do mundo é a base para a reapropriação da consciência em geral, coextensiva ao campo, cujo desenvolvimento só é esclarecido pela cosmologia apresentada em A evolução criadora. 
percepção consciente, ligando-a inexoravelmente à vida e à duração. Sua teoria repõe a relação entre ser e ser percebido como uma relação entre parte e todo, seleção na totalidade: a imagem em si mesma é suas próprias relações com todas as outras, sua solidariedade à "totalidade das outras imagens"; a imagem percebida é a seleção de partes de si mesma pela reflexão da ação possível de uma dentre elas que se fechou. O percebido é seleção, recorte, discernimento num todo que lhe é anterior e mesmo que lhe dá sentido. Isso significa que a teoria bergsoniana da percepção a toma como fenômeno centrípeto, instituído no plano material e originado na esfera exterior ao sujeito: "minha percepção, em estado puro e isolado de minha memória, não vai de meu corpo aos outros corpos: ela está no conjunto dos corpos em primeiro lugar, depois aos poucos se limita, e adota meu corpo como centro" (Bergson 3, p. 63). E a "faculdade" capaz de realizar a limitação no campo, o recorte do quadro pelo obscurecimento do que o envolve é a ação do corpo, sua forma de agir, que é o "princípio verdadeiro" do problema do dualismo.

A percepção é imanente ao mundo, pela imanência do corpo: nesse sentido, ela é contato com a realidade externa, é um processo que se constitui a partir do real. A origem da percepção na ação sobre a matéria configura a base para Bergson deduzir as condições de efetivação da consciência, dadas pela indistinção originária entre percepção e matéria e pela independência entre memória e corpo. A gênese da consciência fundada na percepção expõe as etapas da ação vital e mostra por que estão inexoravelmente ligadas a ela três dimensões da experiência concreta: a distância perceptiva (logo transformada em horizonte e, posteriormente, em espaço); a presença mínima da memória no ato de contração de vibrações, que define o processo perceptivo no tempo (como percepção de alguém, uma subjetividade interiorizante); e o contato com o ato de ligação que é a própria matéria unificada.

Pelo seu fundamento no exercício da vida, a teoria da percepção de Bergson rompe com a abordagem clássica da representação, que 
a considerou sempre como um ato subjetivo essencialmente cognitivo e perdeu-se no labirinto criado para alcançar o mundo objetivo partindo do sujeito: estamos diante de uma "teoria do conhecimento fundada na ação" (Worms 20, cap. 1) que subverte a posição comum do problema da representação. A inversão aqui é clara, iniciando-se pela "ordem ordinária dos termos do problema": com a noção de imagem, da força de seu ponto de partida, Bergson pode mostrar que "a percepção é de início um ato objetivo pelo qual nos colocamos de um só golpe nas coisas, e o que é preciso procurar é como esse ato reveste formas interiores e subjetivas" (Delbos 4, p. 356). Essa imanência da percepção ao mundo oferece, assim, as condições para explicar a diferença entre o para-si e o em-si ${ }^{21}$ pela ação especial do ser vivo, que extrai um quadro do campo de imagens por meio do isolamento, na totalidade, de partes que respondem aos interesses imediatos dirigidos pela carência vital. No limite do contato entre corpos, a vida delimita um horizonte, uma distância, em que partes serão isoladas e corpos singulares serão delimitados. A consciência perceptiva tem sua razão de ser no processo pelo qual o corpo hesita nas suas reações e a imagem percebida pode ser compreendida como o reflexo da ação possível do corpo sobre os objetos exteriores, ou numa região da exterioridade de onde serão recortados os objetos; a percepção é justamente essa figuração simbólica e objetiva da inde-

21 O terreno para a análise psicológica e ontológica, que se realiza pelo estudo da memória e do passado, é todo arrumado, ordenado e arranjado pela teoria da percepção pura, momento em que o trabalho crítico se desenvolve com mais intensidade - o que Bergson procura evitar são as armadilhas do realismo estrito (pensar a percepção à luz do percebido e pela inteligibilidade da coisa), e do idealismo (pensar a percepção à luz da ilusão interiorizante, isto é, partindo da noção de sensação). Idealismo e realismo são as concretizaçôes de hipóteses filosóficas que tornam insolúvel o problema do dualismo (inicialmente entre ideia e coisa, mas ampliado para sujeito e objeto e, ontologicamente, para espírito e matéria). Bergson pretende "cavar por baixo" dessas hipóteses e sintetiza o fio condutor de sua teoria da seguinte maneira: "Partamos, pois, dessa força de agir como do princípio verdadeiro; suponhamos que o corpo é um centro de ação, e vejamos que consequências decorrem daí para a percepção, para a memória e para as relações do corpo com o espírito" (Bergson 3, p. 359). 
terminação da ação do ser vivo. A percepção é, assim, definida como a significação que as imagens assumem nessa relação especial, nessa antecipação exercida pelo corpo dotado de cérebro: ela é, portanto, uma simbolização imanente à vida.

A percepção pura é o momento-chave da inserção do tempo no espaço e da projeção do espaço sobre o tempo, porque ela circunscreve uma espécie de "momento zero" da espacialização. Seu isolamento pela análise responde, então, pelo esclarecimento do campo da experiência concreta como mistura entre espaço e tempo, cujo limite é o instante:

A intrusão do espaço projetado sobre a duração pura cria o instante, possibilita o congelamento e, sobretudo, permite, ao pregar sobre um só instante dois eventos distintos pelo lugar, conceber a simultaneidade, que se pode definir como a intersecção do tempo com o espaço. (Heidsieck 7, p. 49)

A nossa experiência tem sua base no recorte prático do mundo, que se dá, no final das contas, pela inserção de nossa história ou nossa memória no mundo, o que cabe à teoria da memória provar e esclarecer. Seu limite, alcançado teoricamente pela dissociação, nos mostra nessa base um ato de inserção real no campo material, que impõe ao próprio contato a dimensão instantânea, forma imaginária dada na simultaneidade que o Ensaio já apontava como fato mínimo da endosmose pela qual se define a experiência concreta. ${ }^{22}$

22 Na sua análise da noção de tempo homogêneo, ao dissociar os elementos presentes numa representação como "sessenta minutos", ele nos mostra a presença da conservação substancial da interioridade psicológica e sua simultaneidade com algo da exterioridade, na qual o filósofo só podia discriminar, naquele campo em que o Ensaio se colocava, uma “exterioridade sem sucessão", o presente renovado sem sucessão verdadeira. Ali, tratava-se de mostrar como a interioridade respondia pela sucessão, definindo o domínio misto da experiência como resultado de "uma espécie de troca" entre a sucessão interna (sem exterioridade recíproca) e a instantaneidade externa (sem sucessão), um processo "análogo ao que os físicos chamam um fenômeno de endosmose" (Bergson, 3, p. 73). 
A mistura prática que define a nossa vida tem no instante o seu limite que tratamos de compreender, assim como nele encontrar o fundamento das ilusões pelas quais a vida se exerce e sem as quais não pode se exercer. É isso que nos mostra Worms, ao sublinhar que o instante não é somente a condição de um pensamento abstrato do espaço; ele é também

(...) o modo de relação com o espaço concreto das coisas, através da sua sensação ou mais exatamente da sua percepção (...) Ele não é somente um limite abstrato do tempo, é uma relação entre o espaço e o tempo, e uma relação instantânea, ou antes, a instantaneidade como relação deve chamar-se simultaneidade (Worms 18, p. 142)

Se a teoria da percepção pura vem completar o estudo da instantaneidade, ela o faz pela demonstração de que sua base é o corpo e de que sua condição é a memória. Assim, o isolamento da percepção pura e seu posterior redimensionamento como processo temporal — constatação da presença da memória ou consciência imediata no contato imediato cuja base exterior foi restabelecida — são os dois momentos do estudo da consciência que nos dão as condições de solucionar o problema do dualismo - já que a base material e a presença do passado se unem nas atualizações que são os momentos da vida consciente..$^{23}$

Assim, a percepção retira do todo material um quadro e se revela imersa na exterioridade: como ação do corpo, uma imagem entre imagens, ela faz, de início, parte da matéria. Mas a representação propriamente dita, a decantada "ideia" da tradição, é essencialmente um processo da memória sobre o fundo impessoal da percepção. Uma

23 Se há projeção de lembranças subjetivas nos atos perceptivos, ela se dá sobre uma base corporal que é esse recorte do mundo - esse é o sentido da afirmação de Bergson de que "a percepção do ponto P se dá em P e não em nós". Somente mediante o esclarecimento de sua origem, podemos compreender a consciência perceptiva em sua imanência ao mundo e à interioridade psicológica representada, sobretudo, pelas lembranças. 
vez estabelecido o solo material de qualquer ato perceptivo, trata-se então de passar ao estudo da mistura entre percepção e lembrança. A lembrança vai se revelando como processo de materialização gradual de uma totalidade de implicação recíproca cuja virtualidade se faz ressentir na representação propriamente dita, a rememoração ou projeção do passado na ação que se faz. As lembranças pessoais entram numa espécie de coalescência com a percepção atual e, pela compreensão dos sentidos e das funções da memória, Bergson delineia sua solução original para o dualismo. A solução é preparada, sobretudo, pela determinação da diferença de natureza entre percepção pura e memória pura: temos os limites da experiência concreta, cuja diferenciação teórica permite reencontrar a verdade da experiência como duração, como apreensão — intuitiva — dos "todos indivisos" que são as sensações e os movimentos, união entre a qualidade e o movimento, termos irredutíveis dos dualismos clássicos.

Interessa-nos, aqui, ressaltar que o reencontro com a continuidade indivisa da experiência necessita da interrompção da prática que intenciona o fato, o dado à distância logo transformado em objeto. $\mathrm{O}$ desvendamento do processo de ação e dos elementos que nela operam é, portanto, a condição para superar o ponto de vista da práxis, limitado, como nos explica Bergson nas primeiras e talvez mais esclarecedoras considerações sobre seu método, ao que "chamamos ordinariamente de fato: adaptação do real aos interesses da prática e às exigências da vida social" (Bergson, 3, p. 319). Antes de apresentar os resultados de sua aplicação do método intuitivo ao estudo da matéria, final do percurso do livro que resolve o dualismo, ele aponta duas atribuições da intuição: primeiro, ela é sempre a de "uma continuidade, interna ou externa"; segundo, ela é sempre uma busca da dimensão da experiência que se ausenta ou se oculta no domínio da vida comum (a experiência mista pela qual efetivamente vivemos), busca da sua origem ou da experiência "em sua fonte, acima dessa virada decisiva em que ela, infletindo-se no sentido de nossa utilidade, torna-se propriamente experiência humana" (Bergson 3, p. 321). 
Isto é, trata-se de encontrar o momento em que o contato originário com o real sofre uma inflexão no sentido da humanidade - o que, sabemos, significa a inflexão exteriorizante e espacializadora.

Em outros termos, partindo da já citada separação de direito entre os elementos ou fenômenos distintos em natureza e implicados numa totalidade cujo acesso direto nos é vetado, Bergson pôde retomar a gênese de sua mistura como processo em movimento, como ato ou todo contínuo e indiviso. Assim, é a própria endosmose prática o ponto a ser esclarecido e a união dos dois limites, memória e percepção puras, terá sua razão de ser na consideração do instante como momento - o limite da experiência é ainda experiência e não pode ser descrito fora do tempo; ele ocupa espessura de duração e, nessa medida, contrai vibrações num certo ritmo. Isso quer dizer que o percurso do livro explicita o método filosófico como recurso à purificação e retorno ao concreto, à luz do que se estabelece pela dissociação analítica. Da visão instantânea teoricamente isolada pela hipótese da percepção pura, Bergson passa à percepção concreta, que exige considerar outro aspecto fundamental: todo ato de percepção, sendo um contato com o real, é ainda uma ação da consciência, é consciente e, enquanto tal, ocupa espessura de duração. Assim, naquilo a que chamamos instantâneo, há um trabalho de nossa memória e, por consequência, de nossa consciência, que "prolonga uns nos outros, de maneira a apreendê-los numa intuição relativamente simples, momentos tão numerosos quanto se queira de um tempo indefinidamente divisível" (Bergson 3, p. 217).

Está aberta aqui a possibilidade de compreender como percepção e matéria (sensação e movimento) coincidem e como se diferenciam, é possível apreendê-las como realidades metafisicamente distintas, mas em contato - a metafísica da matéria que fecha o livro expõe as principais teses resultantes da compreensão desse contato ou união. Mais explicitamente, a metafísica atingida pela análise psicológica ilumina o impasse que as teorias anteriores legaram ao século XIX: nossas percepções do universo são marcadas por uma heterogenei- 
dade qualitativa, e a ciência nos oferece desse mesmo universo uma imagem de sistema de estímulos homogêneos que as leis da física parecem confirmar veementemente. A explicação para a heterogeneidade das sensações está na ação da memória, no fato decisivo de que cada uma das percepções obtidas se estende ela mesma sobre uma espessura de duração, e a memória condensa uma quantidade enorme de estímulos que nos aparecem continuamente, ainda que sucessivos. Toda percepção é contração de vibrações por nossa consciência, que enquanto consciência é memória imediata, transformação dos estímulos segundo nosso próprio ritmo. Toda percepção é uma constituição de totalidade, é uma espessura indivisa de tempo, é uma conformação do real por condensação num ato único. Segundo o raciocínio que se apresenta, Bergson expõe o que seria o acesso da matéria em si: bastaria "dividir idealmente" essa espessura indivisa de tempo, nela distinguindo a multiplicidade desejada de momentos,

eliminar toda memória, numa palavra, para passar da percepção à matéria, do sujeito ao objeto. Então a matéria, cada vez mais homogênea à medida que nossas sensações extensivas se repartissem sobre um mais número de momentos, tenderia indefinidamente para esse sistema de estímulos homogêneos dos quais fala o realismo sem, é verdade, jamais coincidir inteiramente com eles. (Bergson 3, p. 217)

Assim, no condicional, Bergson anuncia as principais conclusões da metafísica e da solução do dualismo, conclusões que permitem, finalmente, aproximar quantidade e qualidade. O fio condutor da solução reside em superar a exterioridade que se instaura entre, de um lado, a representação do espaço, com movimentos não percebidos e, de outro, a consciência com as sensações inextensivas - é numa "percepção extensiva", ação do corpo-próprio, que sujeito e objeto se uniriam a princípio o aspecto subjetivo da percepção consistiria na contração operada pela memória, e a realidade objetiva da matéria se confundiria com os estímulos múltiplos e sucessivos 
nos quais a matéria se decompõe interiormente - é a interioridade da matéria que seria assim atingida, que se identifica com sua objetividade, cujo conhecimento absoluto e assim metafísico seria, então, obtido. Bergson explicita o que se alcançaria por esse procedimento: "o problema pendente entre realismo e idealismo, em lugar de perpetuar-se em discussões metafísicas, deverá ser tranché pela intuição" (Bergson 3, p. 216).

A consideração da percepção concreta que se segue à teoria da percepção pura é, na verdade, um estudo psicológico centrado na memória. Bergson analisa o processo de reconhecimento atento, que configura a representação propriamente dita, já que a experiência efetiva é a da inserção das lembranças sobre o fundo impessoal da percepção pura. Perceber acaba sendo, no final das contas, uma ocasião para "lembrar-se" e representar um objeto é inserir lembranças sobre o recorte prático, que nada mais é do que a vida se exercendo. ${ }^{24} \mathrm{E}$ o mais fundamental: é pela discussão crítica com as descrições de base associacionista que Bergson recupera a verdade da percepção concreta como processo, e não como justaposição de estados - um processo que vai da totalidade nebulosa das lembranças em estado puro ao seu desenvolvimento em imagens através do corpo. O núcleo dessa retomada de processos conscientes é o esforço para não sacrificar o instável em nome do estável, ou

24 Trata-se do "teórico" das lembranças com utilidade prática imediata: as lembranças úteis vêm mesmo recobrir o "fundo de intuição real, por assim dizer, instantâneo sobre o qual se estende nossa percepção exterior" (Bergson 3, p. 213). A lembrança de intuições anteriores é justamente o que liga essa intuição atual a toda série de eventos subsequentes em nossa memória. Nesse sentido, a intuição real ou o contato direto com o mundo que marca a percepção, a própria coincidência entre a percepção e o objeto, não é senão uma ocasião para a lembrança útil atualizar-se, e perceber acaba por ser não mais que uma ocasião para lembrar-se. No seguimento do livro, trata-se de tirar os significados dessa conquista: se a percepção é contato com o real, há uma coparticipação entre sensação e movimento, entre interioridade e exterioridade, entre a natureza da percepção que se estende e a natureza da matéria sobre a qual ela se estende. A metafísica da matéria explorará essa participação mútua: ela não faz senão tirar as consequências metafísicas desse percurso teórico, dessa análise dissociativa que é a teoria da percepção pura. 
seja, não sucumbir à tendência do intelecto e assim escapar a uma de suas ilusões constitutivas, que expusemos anteriormente. Há duas direções da descrição completa do reconhecimento a serem ressaltadas; em primeiro lugar, Bergson abandona o percurso comum que a ciência adotou para si e que consiste em explicar tudo à luz do resultado do processo (tomado como elemento estático): a lembrança representada. Nessa chave de explicação, o resultado, entidade da ordem da "coisa", substitui o movimento que parte do espírito e vai em direção à matéria. Em segundo lugar, o acompanhamento do processo de projeção de lembranças na ação que se efetiva, nossa experiência no sentido mais essencial, mostra a materialização do espírito própria à vida. Aqui reside o princípio sobre o qual Bergson assentará o estudo da vida e o estabelecimento do verdadeiro evolucionismo em A evolução criadora.

$\mathrm{O}$ retorno à experiência efetiva da representação nos oferece a gênese da materialização do imaterial, da progressão contínua do passado para o futuro, das lembranças subjetivas à sua objetivação no mundo, processo que Bergson retoma em $O$ esforço intelectual. No ato supremo do espírito, aquele pelo qual compreendemos e interpretamos as imagens com que entramos em contato, há um movimento do espírito "de um plano a outro" da vida mental — ainda lidamos com um apelo à rememoração. Ao examinar esse processo, Bergson acrescenta análises elucidativas sobre o modo de ser imaterial, próprio à virtualidade da lembrança pura, agora atribuído ao "esquema representativo do todo" como representação abstrata que "implica uma penetração recíproca de todos os elementos uns nos outros" (Bergson 3, p. 938). A passagem do esquema à imagem, da totalidade de imbricação à exteriorização objetiva, é o processo paradigmático para compreender a espacialização do tempo, a transformação progressiva da imbricação recíproca à justaposição em partes, e apenas queremos ressaltar aqui que são os processos mentais como o aprendizado de um exercício ou o esforço de apelo à rememoração que nos ensinam sobre a metafísica da vida. $\mathrm{O}$ fim 
do processo representativo é a determinação ou representação imaginada, mas sua verdade e suas lições estão na passagem em questão. Bergson não poderia expressar melhor o alcance do estudo do esforço mental quando conclui seu texto pela explicitação do seu vínculo "ao problema geral da metafísica da causalidade":

Esta operação, que é a própria operação da vida, consiste numa passagem gradual do menos realizado ao mais realizado, do intensivo ao extensivo, de uma implicação recíproca de partes à sua justaposição. $\mathrm{O}$ esforço intelectual é algo desse gênero. Ao analisá-lo, apreendemos tanto quanto possível, sobre o exemplo mais abstrato e consequentemente mais simples, essa materialização crescente do imaterial que é característica da atividade vital. (Idem, ibidem, p. 959)

A originalidade da metafísica bergsoniana reside na capacidade do filósofo de trazer os problemas e seus núcleos conceituais ao terreno da temporalidade. Material e imaterial, como vimos, são compreendidos agora como explicitações do presente e do passado, do atual e do virtual. O centro da solução do problema metafísico do dualismo é a revelação da efetividade do presente como movimento do passado avançando ao futuro - o presente, estritamente, quase não é, ou "nada é menos que o momento presente" (Bergson 3, p. 291) enquanto limite instantâneo e indivisível. Se o presente, quando nele tentamos nos concentrar, não é ainda ou já não é mais, tudo o que existe é passado e projeção para o futuro; em outros termos, se a frase que pronuncio se distancia de mim no próprio desenrolar de sua efetivação, aquilo que realmente percebemos junto ao nosso corpo, ponta movente da vida mental que se insere no mundo, é o que acabou de passar - na expressão escolhida por Bergson, o "passado imediato". É assim que ele formula o significado dessa inversão: o presente concreto "realmente vivido pela consciência" (Idem, ibidem) consiste em grande parte em passado imediato. A verdade da percepção é rememoração, mas as vibrações rememora- 
das tomam parte na matéria e não são frutos de nossa imaginação, conforme a teoria da percepção pura já demonstrou. Tudo se passa como se Bergson nos revelasse, nos instantes da vida de alguém, a atualização do passado que separa e religa a duração virtualmente una. Reapreender o presente da vida consciente como momento em que esse milagre da união se dá é, portanto, a consequência capital da investigação sobre a memória.

Eis o que nos interessa: o processo de dissociação, que configura a teoria da percepção pura, isola o aporte externo da percepção e possibilita o retorno à percepção concreta, agora liberada da confusão inevitável que seu próprio funcionamento institui. Se a metafísica da matéria alcançada por esse trajeto pode ser identificada a uma "metafísica da percepção" (Worms 18, p. 135), é porque a dualidade dessa última mostra-se como ponto-chave da investigação. A percepção como ação de recorte do mundo pelo corpo impõe à totalidade movente da matéria uma forma que a desnatura; mas, ao fazê-lo, introduz nessa totalidade a indeterminação que funda a liberdade. Nesse sentido, ela intensifica e promove a espiritualidade própria à materialidade, sua duração. A percepção que oculta a matéria em movimento ao impor-lhe a forma espacial é a mesma que, depois do tratamento analítico como etapa metodológica, revela sua origem como contato entre o corpo e o mundo - ou, antes, pertencimento a uma extensividade própria à materialidade - nesse momento, a percepção torna-se intuição. Bergson pode voltar aos aspectos subjetivos da percepção a partir da constatação de sua origem no mundo, e esse retorno é a recuperação da dimensão concreta do processo, isto é, de sua verdade no tempo. Assim, a teoria da memória, que é o coração do livro, nada mais faz do que retornar aos processos psicológicos efetivos, ou seja, o sujeito empírico em ato, à luz do equacionamento desenhado por uma etapa que podemos identificar como transcendental, a determinação das condições de possibilidade da ação perceptiva ou vital. 
A teoria da percepção mostra a extensividade imediatamente dada na sensação, enquanto processo corporal e, assim, material. Ela lega ao estudo do passado a tese de sua incomensurabilidade com aquilo que não é ação, que existe fora da atualidade do corpo: lembrança e percepção são distintas em natureza. $\mathrm{O}$ estudo da lembrança apresenta assim características especiais: toma seu objeto como processo, evitando as armadilhas de confundir a lembrança em atualização melhor dizendo, atualizando-se - com o produto final, a representação fixa e determinada para a qual esse processo aponta e que nosso entendimento toma como verdade da representação propriamente dita. Logo, fica claro que o centro da redescrição psicológica reside na diferenciação entre passado e presente, entre aquilo que integra nossa existência sem presença atual - o que não age mais - e o momento consciente propriamente dito, a ação que se realiza com projeção para o futuro e da qual não podemos em nenhum sentido nos afastar inteiramente, a não ser na morte. O presente é sensóriomotor, é a "consciência que tenho de meu corpo" como conjunto de sensações experimentadas e movimentos projetados no espaço que constituem a sua própria materialidade. O passado em si é delimitado nesse estudo no momento em que Bergson pode destacar o campo da "lembrança pura", conjunto de fatos pessoais vividos e conservados ininterruptamente por uma memória espontânea, cuja presença em nossa vida podemos constatar indireta mas inexoravelmente. A totalidade de nossa vida passada, das representações obtidas no avanço para o futuro, é conservada e como que nos assombra: ela nos envia claros sinais de sua influência, sua importância, seu peso capital para a vida mais livre e espiritualmente mais elaborada. A lembrança pura tomada em si mesma é marcada por uma impotência radical, pela incapacidade de atualização completa por não dizer "respeito a nenhuma parte de meu corpo" (Bergson 3, p. 282), por não fazer parte de nenhuma ação que se realiza. Aquilo que dela pode se atualizar é sua ramificação em movimentos que a transformam em lembrança-imagem — separação da totalidade, do mesmo 
modo que o recorte da matéria isolava imagens do todo. A representação é, então, materialização de lembranças, atualização do virtual, passado virando futuro, união entre o espírito e o corpo.

Finalmente, cabe acrescentar a abertura à etapa seguinte da filosofia bergsoniana que as teorias da percepção e da memória oferecem: elas nos mostram que a existência individual exige a constituição de um corpo-próprio, e nela tem origem, isto é, aquele que percebe e sente, age no mundo de modo a efetivar a percepção de objetos e a percepção de si mesmo - sentido último da dimensão consciente da percepção. É esse corpo, como memória, com sua determinação e sua conservação, que explicita a individuação indispensável à vida e ela se dá pela materialização do imaterial, isto é, pela constituição de um corpo organizado como única forma que o espírito tem, de fato, para inserir-se na matéria. Encontramos todas as condições para a elaboração da hipótese do elã vital como explicação da efetividade da vida. Mas é aqui que o papel do corpo - delimitado justamente pela teoria da percepção - adquire seu estatuto mais essencial: o elã vital seria "em si" uma vida que não se efetiva, uma espécie de contrassenso - assim como seria, nas palavras de Thibaudet, um psíquico sem um físico, "multiplicidade infinita de tendências" que não agem. Para que o viver seja uma realidade é preciso corpo, não qualquer corpo, mas esse corpo especial descrito em Matéria e memória. Corpo que age, percebe e sente, um corpo-memória, corpo espiritualizado, aquele que institui um sujeito e possibilita a vida: "a existência do corpo aparece, em relação ao elã vital, como uma condição essencial de seu êxito"(Thibaudet 14, p 90).

Enfim, se o mérito do livro é apresentar uma teoria da representação inserida numa filosofia da consciência em torno da noção indispensável de corpo-próprio, uma última característica de seu percurso se evidencia como etapa de fundamentação da teoria da vida: o fato de a análise da consciência tem se organizado a partir da noção de imagem, a força de seu ponto de partida, que dissolveu o dualismo entre matéria e espírito progressiva e inelutavelmente: 
"se é verdade que o itinerário bergsoniano é marcado pela passagem da duração interna à duração cósmica, se a filosofia da interioridade da consciência é introdução à filosofia da natureza, é porque há um meio-termo que permite o trânsito de um a outro polo" (Prado Jr.12, p. 167). Esse meio-termo é a imagem, noção que impulsiona a investigação da práxis e sua superação, a introdução à verdadeira metafísica. O papel da teoria da percepção, aliada ao estudo da memória, consiste assim em permitir a "coesão entre filosofia da subjetividade humana e a filosofia da vida, entre a consciência humana e a consciência coextensiva à vida" (Idem, ibidem). A intuição da duração realiza-se, aqui, pelo retorno ao imediato da inserção no mundo, que é também inversão do ponto de partida da tradição na passagem da psicologia à metafísica, tal como Bergson bem sintetiza:

As coisas se esclarecem assim se vamos da periferia da representação ao centro, como faz a criança, como nos convidam a fazê-lo a experiência imediata e o senso comum. Tudo se obscurece, ao contrário, e os problemas se multiplicam, ao pretendermos ir do centro à periferia, como fazem os teóricos. (Bergson 3, p. 196)

\section{Referências bibliográficas}

1. Barbaras, R. “Le tournant de l'experience: Merleau-Ponty et Bergson”. In: Philosophie, n. 54, 1997.

2. Bergson, H. Mélanges. Paris: PUF, 1972.

3. . Oeuvres. Paris: PUF, 1991.

4. Delbos, V. "Matière et mémoire par Henri Bergson, Étude critique”. In: Revue de Métaphysique et Morale, 1897.

5. Deleuze, G. Bergsonismo. Trad. Luiz B. L. Orlandi. São Paulo: 34, 1999.

6. DuRING, E. "Presénce et répétition: Bergson chez les phénoménologues". In: Critique, LIX, n. 678, nov.2003.

7. Heidsieck, F. Henri Bergson et la Notion d'Espace. Paris: PUF, 1961.

8. MARquet, J-F. “Durée bergsonienne et temporalité". In: Bergson, la durée et la nature. Ed. Vieillard-Baron. Paris: PUF, 2004. 
9. Merleau-Ponty, M. Fenomenologia da percepção. São Paulo: Martins Fontes, 1994. (Coleção Tópicos)

10. PinTo, D. C. M. “Crítica da tradição, refundação da metafísica e descrição da experiência - Bergson e Merleau-Ponty”. In: Questões de Filosofia Contemporânea. São Paulo/Curitiba: Discurso Editorial/UFPR, 2006, p. 25-40.

11.___. "O tempo e seus momentos interiores". In: Analytica, vol. 9, n. 2, 2005.

12. Prado JR., B. Presença e campo transcendental: Consciência e negatividade na filosofia de Bergson. São Paulo: Edusp, 1989.

13. Silva, F. L. Bergson, intuição e discurso filosófico. São Paulo: Loyola, 1994.

14. Thibaudet, A. Le Bergsonisme. Paris: Nouvelle Revue Française, 1923.

15. VieILlard-BARON, J-L. “L'intuition de la durée, expérience intérieure et fécondité doctrinale”. In: Bergson, la durée et la nature. Paris: PUF, 2004.

16. Worms, F. Annales Bergsoniennes. vol. 1: Bergson dans le siècle. Paris: PUF, 2002.

17. ___. Annales Bergsoniennes. vol. 2 : Bergson, Deleuze, la Phénoménologie. Paris: PUF, 2007.

18. _. Bergson: les deux sens de la vie. Paris: PUF, 2004.

19. ___ .A concepção bergsoniana do tempo". In: Doispontos. n. 1, 2004.

20. __ . Introduction à Matière e Mémoire de Bergson. Paris: PUF, 1997. 